OPEN ACCESS

Edited by: Alon Shepon

Tel-Aviv University, Israel

Reviewed by:

Aida Turrini,

Independent Researcher, Rome, Italy

Gidon Eshel,

Bard College, United States

*Correspondence:

Carmen Byker-Shanks

cbykershanks@montana.edu

Specialty section:

This article was submitted to Nutrition and Sustainable Diets,

a section of the journal

Frontiers in Sustainable Food Systems

Received: 12 May 2021 Accepted: 22 December 2021 Published: 01 February 2022

Citation:

Ebel $R$ and Byker-Shanks C (2022)

Short-Term Impacts of COVID-19 Public Health Regulation on Consumer

Food Purchases: A Case Study From a Grocery Store in Montana. Front. Sustain. Food Syst. 5:708504.

doi: 10.3389/fsufs.2021.708504

\section{Short-Term Impacts of COVID-19 Public Health Regulation on Consumer Food Purchases: A Case Study From a Grocery Store in Montana}

\author{
Roland Ebel ${ }^{1}$ and Carmen Byker-Shanks ${ }^{2 *}$ \\ ${ }^{1}$ Food and Health Lab, Department of Health and Human Development, Montana State University, Bozeman, MT, \\ United States, ${ }^{2}$ Gretchen Swanson Center for Nutrition, Montana State University, Bozeman, MT, United States
}

The mitigation measures (e.g., lockdown policies) in response to the COVID-19 pandemic impacted food systems in unprecedented ways, in both scope and immediacy. Food retail, for example, changed fundamentally in the United States, as access to nutritious food became limited, supply chain shortages were common, and mandatory public health measures led to behavior changes among customers and employees. In the present case study, we hypothesized that these changes led to food purchasing shifts of grocery store consumers. Such shifts are seen as an outcome of both endogenous factors at the individual level and exogenous factors at the government/policy level. Our case study sought to better understand how the pandemic and associated regulations shaped consumer food choices during the "hard" lockdown period in Montana during 2020. We selected 112 food products based on the highest sales in a Gallatin County, Montana, grocery store. They were analyzed by predefined food groups aligned to the Dietary Guidelines for Americans 2020. All purchases were processed for each selected food item during March and April 2019 (before the pandemic) and March and April 2020 (during the lockdown in Montana). To further describe the pandemic experiences qualitatively, we conducted semi-structured interviews with managers and employees from two stores in Gallatin County. Overall, we found that consumers increased purchases in most food groups during the pandemic, including nutrient-dense and energy-dense products, most outstandingly for starchy vegetables, legumes, and convenience food. Products with long shelf-life and that required preparation at home were preferred. Endogenous causes, specifically panic and rushing, were likely stronger drivers of consumer behavior and food choices than regulations. Nonetheless, lockdown policies impacted consumer food purchases. We present a series of policy and practice recommendations based on our findings and the emerging literature on this topic.

Keywords: food purchase, grocery store, food choice, food groups, consumer behavior, COVID-19 lockdown, pandemic regulation 


\section{INTRODUCTION}

The COVID-19 pandemic, especially in the early months of 2020 , changed the way food was obtained and consumed worldwide (Boyacı-Gündüz et al., 2021). In the United States (US), the COVID-19 pandemic forced new food shopping habits, shifted spending, closed businesses, changed business operations, disrupted supply chains, increased household cooking, and decreased food consumption outside the home (Nicola et al., 2020; Poppick, 2020).

The magnitude, reach, and duration of the pandemic, alongside the unpreparedness of politicians, markets, and individuals to respond to it, generated ambiguity and uncertainty, causing the most massive disruption of the US food system since World War II (Naja and Hamadeh, 2020; Orden, 2020; Zurayk, 2020; Chenarides et al., 2021). Apart from its negative impacts on US food production (Béné, 2020), food processing and distribution (Corkery and Yaffee-Bellan, 2020), and food retail (Hobbs, 2020), COVID-19 altered food environments, increased food insecurity, caused irregular consumption, and led to unhealthy eating patterns among large parts of the population (Aday and Aday, 2020). Unhealthy eating, which is associated with higher caloric intake and increased risk of obesity and diabetes, amplified the risk of developing severe COVID-19 symptoms (Scully et al., 2009; Byker-Shanks et al., 2020a).

For high-income countries, such as the US, exogenous food system shocks including pandemics can alter food purchasing patterns in the built market and other food environments. That is, changes in the quality and cost of food can have profound implications for individual dietary quality and personal finances, both of which influence health and wellbeing (Hirvonen et al., 2020). To mitigate these negative consequences on the food supply and to increase the resilience to such stressors, it is essential to understand how the most recent food system crisis, COVID-19, affected food purchasing patterns, and their impacts on public health.

Research about consumer food purchasing in retail settings during previous pandemics and similar outbreaks found that behavioral change was an outcome of two stimuli: (1) endogenous, individual-level motivations, and (2) exogenous, mostly government-enforced policies (Wen et al., 2005). Both stimuli regularly affect each other. In the very early stages of the pandemic, the two stimuli may be challenging to distinguish, as individual consumers were frequently expected to subsume the role of the government in the absence of consistent policies (Aboelenien et al., 2021). However, evidence from previous pandemics demonstrated that in the long term, regulations have a strong direct (e.g., food access and food supply) and indirect (e.g., consumer spending) effect on the quality, quantity, and cost of food purchased (Nicosia, 2005; Bhattacharya, 2012). Pandemic regulations do influence public health not only during a crisis but also beyond its conclusion, as they can cause long-term shifts in lifestyles (Nicosia, 2005).

Research about the positive and negative (unintended) consequences of pandemic regulations on public health and nutrition is scarce. Most available data refer to historic pandemics, non- communicable diseases (NCDs), or are limited to a few countries (Harrison, 2016). The COVID-19 pandemic, especially in its early stage, was a unique opportunity to study these consequences, as it was both an unfortunate and unprecedented natural experiment where immediate health effects were present and the almost simultaneous global governmental responses to the crisis were ongoing (Harrison, 2016).

Given that food purchased drives what consumers eat and food consumption markedly influences health, shifts in food purchasing patterns due to COVID-19 regulations were expected to change public health outcomes. However, the extent to which these regulations had changed food purchasing habits is largely unknown. We address this knowledge gap by conducting a case study on a grocery store in Gallatin County, Montana (MT).

In our case study, we applied methods from economics and qualitative research to assess the impact of pandemics and associated regulation measures on grocery store food purchases and discuss potential diet and health outcomes. We hypothesized that, during the early stage of the pandemic in March and April of 2020, state and county COVID-19 legislation, as well as individual customer perceptions, had a significant impact on consumers' food purchases from grocery stores in Gallatin County, Montana (MT). Our research question was: What was the immediate impact of public health regulations placed during the early stage of the COVID-19 pandemic and respective customer perceptions on consumer food purchasing patterns in Gallatin County, Montana?

Our objective was to understand how food consumption patterns and food purchasing behaviors changed during the initial months of the pandemic, with a specific interest in their alignment with recommendations from the Dietary Guidelines for Americans 2020. In the key informant interviews, we examined how the pandemic affected the economy of local grocery stores and the working conditions of their employees. We aim to contribute to the development of pandemic regulation that not only effectively prevents the spread of diseases but also reduces potential negative externalities on consumer nutrition, local food retailers, and the well-being of their personnel.

Specifically, we selected 112 food products based on their popularity among customers of a grocery store in Gallatin County, MT, and categorized them based upon food groups and subgroups of the Dietary Guidelines for Americans (Krebs-Smith et al., 2018). We then processed all food purchases in this store for each selected product from pre to post COVID-19 regulations, comparing food purchases during March and April of 2020 (the period of most severe lockdown measures in MT) with food purchases in the same store in March and April of 2019. To learn more about the perceptions and working conditions of grocery store personnel during the initial stage of the pandemic, we conducted semi-structured interviews with managers and employees of two grocery stores in Gallatin County.

\section{BACKGROUND}

\section{US Consumer Responses to the COVID-19 Pandemic}

Despite being the wealthiest nation in the world, in 2020, the US had the highest number of COVID-19 cases and deaths in the 
world (Blum, 2020), which made COVID-19 the third-leading cause of death in 2020, only behind heart disease and cancer (Huizar et al., 2020; Ahmad and Anderson, 2021). Pandemics of this magnitude, from the Black Plague in the Middle Ages to the Spanish Flu in the early twentieth century, have always caused enormous societal change (Reeves et al., 2020), including altered access to food (Wen et al., 2005).

In the twenty-first century, different crises and epidemics have affected consumer retail food purchase behavior, anticipating patterns observed during the COVID-19 pandemic (Lusk and Briggeman, 2009; Ellison et al., 2021). For example, during the SARS epidemic in 2003, panic buying sharply increased in several Asian countries, partially triggered by misinformation on the internet (Ding, 2009). The global financial crisis in 2008 and 2009 caused customers worldwide to cut down their food purchasing expenditures (Cranfield, 2020). The swine flu pandemic in 2009 increased food safety concerns related to airborne viruses, causing US customers to wear face masks in grocery stores (Goodwin et al., 2009).

Overall, grocery store consumer behavioral changes during pandemics and other crises have been related to individuallevel motivations (e.g., fear of contagion) and external factors, specifically market changes and government-enforced policies (Wen et al., 2005; Melo, 2020). In their food choices under past crises, consumers overwhelmingly valued food safety, followed by nutrition, taste, and price (Lusk and Briggeman, 2009). However, the economic and social stress and the legal constraints for shopping in grocery stores during COVID-19 went beyond the implications of similar events in the past (Ellison et al., 2021).

Since the outbreak of the COVID-19 pandemic, consumer behavior, and food retail experiences have undergone significant changes (Martin-Neuninger and Ruby, 2020; Chenarides et al., 2021). Early US consumer responses to COVID-19 can be divided into three phases: (1) reaction, (2) coping, and (3) resilience (Kirk and Rifkin, 2020).

The reaction phase occurred around March 11, 2020, when COVID-19 was classified as a pandemic by the WHO. This classification caused a shift in consumer risk framing and triggered panic buying as consumers, driven by distrust in the global food supply chain, attempted to defend against a perceived threat (Kirk and Rifkin, 2020; Chenarides et al., 2021). Consumer food expenditures increased significantly, and anxieties about food shortages characterized food purchases, including hoarding and panic buying of products perceived as essential (Aboelenien et al., 2021). Stockpiling of essential goods limited in supply is the result of/perceived and actual) scarcity. It is a widely rational behavior (Timmer, 2012; Kirk and Rifkin, 2020; Ellison et al., 2021). Hoarding behavior (not to be confused with compulsive hoarding), is less planned than stockpiling. It refers to collecting and safeguarding a large number of possessions, more than required for present needs (Frost and Hartl, 1996). Possession and acquisition of specific products can restore consumers' perceived loss of control during a crisis, giving them a sense of security and comfort. This may lead to panic buying, which is common in times of uncertainty but goes beyond a rational response (Kirk and Rifkin, 2020; Martin-Neuninger and Ruby, 2020;
Chenarides et al., 2021). In the early stage of COVID-19, hoarding together with supply chain disruptions triggered temporary stock-outs which many customers perceived as traumatic (Pantano et al., 2020). Because of empty shelves, customers frequently had to visit multiple retailers to find desired items. Communities with already reduced access to food retail, especially rural populations and communities of color, were disproportionately challenged (Belarmino et al., 2020; Niles et al., 2020).

In the coping phase, later in March 2020, customers started adopting behaviors to protect themselves and others. This phase was characterized by almost daily policy communications on protecting essential workers, emphasizing the individuals' role in mitigating the crisis. Retail and food companies developed their own pandemic rules and initiatives (Kirk and Rifkin, 2020; Aboelenien et al., 2021). Also, although Americans had spent more money than ever from home than food at home in 2019, the 2020 pandemic regulations caused that demand switched almost dollar for dollar from restaurants to retail stores (Conley and Lusk, 2019; Goddard, 2020; Mendez-Carbajo, 2021).

During the coping phase and beyond, numerous grocery store customers refused to obey pandemic regulations, often caused by misinformation in the media (Aboelenien et al., 2021). It has been demonstrated in previous crises that if consumers perceive that regulation is contrary to their beliefs, they see their attitudinal and behavioral freedoms threatened, leading to a state of psychological reactance (Fitzsimons and Lehmann, 2004).

By the end of April 2020, consumers became more resilient, proactively adapting to the new situation (Kirk and Rifkin, 2020). Simultaneously, customers decreased their spending because of the incipient recession (Aboelenien et al., 2021; Mendez-Carbajo, 2021). In this phase, food markets widely stabilized and further adapted to the new COVID-19 consumer status quo (Laato et al., 2020).

Throughout the early stage of the pandemic, consumers changed their food retail shopping routines in several manners. For example, most households took fewer in-person trips to the grocery store and customers partially shifted away from their regular shopping destinations (Wang et al., 2020; Ellison et al., 2021). Although stores remained the principal places of food purchase (Chaganti et al., 2020), grocery pick-up and online grocery deliveries expanded significantly (Gray, 2020; Hobbs, 2020).

As consumers spent more time at home and intensified meal preparation, they increased spending on basic food products, such as flour and eggs (Aday and Aday, 2020; Melo, 2020; BoyaclGündüz et al., 2021). A further trend included products with long shelf life, including dried or canned foods, pasta, and frozen foods. This was contrary to the previous 10 years when sales of produce, dairy, and other fresh items increased at the expense of nonperishable products (Aday and Aday, 2020; Chenarides et al., 2021). In addition, sales of processed food increased because home-office working frequently impeded preparing three fresh meals per day (Information Resources Inc., 2020; Melo, 2020). Finally, demand for alcoholic and non-alcoholic beverages grew considerably. At a minor level, consumers also purchased more fresh products (Information Resources Inc., 2020). 
TABLE 1 | Overview of studies on US food consumption patterns during March and April 2020.

\begin{tabular}{|c|c|c|c|c|}
\hline References & Method and sample & $\begin{array}{l}\text { Study location and } \\
\text { time }\end{array}$ & Study focus & Notable findings \\
\hline Chenarides et al. (2021) & $\begin{array}{l}\text { Cross-sectional online } \\
\text { survey }(n=861)\end{array}$ & $\begin{array}{l}\text { Phoenix, AZ, and } \\
\text { Detroit, MI; May } 2020\end{array}$ & $\begin{array}{l}\text { Food shopping } \\
\text { behaviors and } \\
\text { consumption during } \\
\text { lockdown }\end{array}$ & $\begin{array}{l}\text { - } 66 \% \text { of surveyed consumers decreased and } 21 \% \\
\text { increased store visits during pandemic. } \\
\text { - } 47 \% \text { bought more than usual; } 75 \% \text { bought "all } \\
\text { food they could get." } \\
\text { - Food consumption patterns for major food groups } \\
\text { were widely constant with slight increases in frozen } \\
\text { food. } \\
\text { - Fresh produce and dairy consumption increased } \\
\text { among households with children. } \\
\text { - For } 42 \% \text {, snacking increased. } \\
\text { - } 48 \% \text { reduced meal take-out. } \\
\text { - } 50 \% \text { consumed less fast food. }\end{array}$ \\
\hline DeBroff (2020) & $\begin{array}{l}\text { Cross-sectional online } \\
\text { survey }(n=630)\end{array}$ & US-wide; May 2020 & $\begin{array}{l}\text { Grocery store customer } \\
\text { preferences and } \\
\text { concerns during } \\
\text { lockdown }\end{array}$ & $\begin{array}{l}\text { - } 56 \% \text { of consumers were worried about not finding } \\
\text { specific foods. } \\
\text { - } 70 \% \text { consumed more food during lockdown. } \\
\text { - } 47 \% \text { consumed more sweets, } 43 \% \text { more fruits, } \\
42 \% \text { more vegetables, } 30 \% \text { more meat, chicken, } \\
\text { or fish. } \\
\text { - } 24 \% \text { consumed fewer vegetables, } 21 \% \text { less fruit, } \\
19 \% \text { less animal protein. }\end{array}$ \\
\hline Ellison et al. (2021) & $\begin{array}{l}\text { Longitudinal online } \\
\text { survey }(n=1,370)\end{array}$ & $\begin{array}{l}\text { US-wide; March and } \\
\text { April } 2020\end{array}$ & $\begin{array}{l}\text { Consumer retail } \\
\text { grocery shopping } \\
\text { behavior change }\end{array}$ & $\begin{array}{l}\text { - Purchases of shelf-stable milk decreased } \\
\text { constantly. } \\
\text { - Minor decreases eggs and dry staples purchases } \\
\text { after first weeks. } \\
\text { - Expenditures on food away from home significantly } \\
\text { declined. } \\
\text { - Taste was the most important food value, ease of } \\
\text { preparation least important. }\end{array}$ \\
\hline $\begin{array}{l}\text { Goolsbee and } \\
\text { Syverson (2021) }\end{array}$ & $\begin{array}{l}\text { Analysis of cellular phone } \\
\text { records data on } \\
\text { customer visits ( } n>2.25 \\
\text { million businesses across } \\
\text { industries). }\end{array}$ & $\begin{array}{l}\text { US-wide; March to } \\
\text { May } 2020\end{array}$ & $\begin{array}{l}\text { Preferences for } \\
\text { purchasing locations, } \\
\text { methods, and time } \\
\text { windows (not limited to } \\
\text { grocery stores) }\end{array}$ & $\begin{array}{l}\text { - Reallocation of consumers from nonessential to } \\
\text { - While overall consumer traffic fell by } 60 \% \text { points, } \\
\text { legal restrictions are only responsible for } 7 \% \text { points } \\
\text { decrease. } \\
\text { - Customers avoided larger, busier stores in favor of } \\
\text { smaller options with fewer visitors. } \\
\text { - When COVID-19 is spreading at an increasing } \\
\text { rate, consumers reduce shopping inside } \\
\text { grocery stores. }\end{array}$ \\
\hline Wang et al. (2020) & $\begin{array}{l}\text { Cross-sectional online } \\
\text { survey via Amazon } \\
\text { Mechanical Turk ( } n= \\
2,500 \text { ) }\end{array}$ & $\begin{array}{l}\text { US-wide; April and } \\
\text { May } 2020\end{array}$ & $\begin{array}{l}\text { Consumer retail } \\
\text { grocery shopping } \\
\text { behavior change during } \\
\text { lockdown }\end{array}$ & $\begin{array}{l}\text { - Customers reduced frequency of store patronage, } \\
\text { travel time, and in-store duration. } \\
\text { - } 43 \% \text { of customers visited a grocery store } \\
2-3 \text { times per week pre-COVID, this } \\
\text { number decreased to } 23 \% \text { during lockdown. } \\
\text { Simultaneously, store visits } 2-3 \text { times per month } \\
\text { doubled from } 12 \text { to } 24 \% \text { of customers. } \\
\text { - Store visits before } 1 \mathrm{pm} \text { decreased from } 54 \% \\
\text { pre-COVID to } 33 \% \text { during lockdown. } \\
\text { - Consciousness on in-store safety increased. } \\
\text { - Increased spending at both, brick-and-mortar, } \\
\text { and online stores. }\end{array}$ \\
\hline
\end{tabular}

Apart from sales data, several studies have explored US consumer preferences and food consumption patterns during March and April 2020 (Table 1). Accordingly, 70\% of consumers ate more food during the lockdown (DeBroff, 2020; Chenarides et al., 2021), while meal take-out decreased sharply (Chenarides et al., 2021; Ellison et al., 2021). Over $40 \%$ of participants in a US survey stated that they increased their consumption of fruits and vegetables during the pandemic, while $30 \%$ said they ate more animal-based protein (DeBroff, 2020). Consumption of snacks and sweets also increased (DeBroff, 2020; Chenarides et al., 2021).

Despite disruptions of access to food outlets, growing unemployment, and altered food prices (Béné, 2020; Naja and Hamadeh, 2020), US consumer demand for almost all food increased in March 2020, and for many products substantially (Information Resources Inc., 2020; US Census Bureau, 2020b). Specifically, food and beverage sales increased by $26.9 \%$ between 
February and March 2020, decreased again by $12.8 \%$ in April 2020 , and then widely stabilized at least $7.5 \%$ above the 2019 levels in the following months (Melo, 2020; US Census Bureau, 2020b).

\section{Impact of the COVID-19 Pandemic on US Consumer Food Security and Well-Being}

The COVID-19 pandemic affected all dimensions of food security (Niles et al., 2020; Boyacı-Gündüz et al., 2021). In March 2020 , food insecurity, especially due to limited food affordability, increased drastically in the US. Recommendations to stock up on food and limit trips to grocery stores were barely achievable for households with low incomes (CDC, 2020c). Limited food affordability immediately affected persons whose food security was unchallenged before the pandemic (Wolfson and Leung, 2020). A population-level survey from Vermont, conducted in March and April 2020, showed that 35.5\% of food-insecure households could be classified as newly food insecure (Niles et al., 2020). In March 2020, 44\% of low-income adults in the US were classified as food insecure, numbers significantly beyond levels seen during the Great Recession. Asian, Hispanic, and especially black Americans were most affected (Huizar et al., 2020; Morales et al., 2020; Wolfson and Leung, 2020).

While newly food-insecure households selected coping strategies related to disrupted eating patterns (i.e., eating less, buying different, and cheaper foods), households with food insecurity before COVID-19 emphasized government programs and food pantries or accepted food from friends and family (Niles et al., 2020). Healthy diets, thus, became unreachable for an increasing number of households. In a national survey, $41 \%$ of food-insecure individuals reported buying fewer fresh items (i.e., milk, meat, fruits, and vegetables) than before the pandemic (Leone et al., 2020). Not only are poor diets considered the main cause of NCDs and premature deaths globally (Afshin et al., 2019); NCDs also caused some of the most severe outcomes for COVID-19 patients (CDC, 2020b).

Furthermore, the pandemic represented a sudden psychological disruption to customers and employees (BoyactGündüz et al., 2021), especially for families with children (Patrick et al., 2020). Due to health and financial concerns, overall uncertainty, and the disruption of daily routines (due to quarantining and home-office employment), the pandemic resulted in boredom, loneliness, fatigue, frustration and anxiety, stress, insomnia, denial, anger, psychological distress up to post-traumatic stress disorder, and depressions (Galea et al., 2020; Torales et al., 2020; Xiong et al., 2020), often triggering "self-medication" through increased intake of sugar, other carbohydrates, fats, and proteins (Aday and Aday, 2020) as well as alcohol and other drugs (Galea et al., 2020; Kalil, 2020).

\section{Impact of the COVID-19 Pandemic on US Food Supply Chains and Retail}

COVID-19 caused major changes in the distribution, sale, purchase, preparation, and consumption of food across the US (Leone et al., 2020; Naja and Hamadeh, 2020; Zurayk, 2020). During March and April 2020, almost all food supply chains were affected by the pandemic, most outstandingly perishable goods, food grains, bakery items, meat, and dairy (Laborde et al., 2020; Singh et al., 2020). Some of these products were sold at a loss or discarded because they could not be marketed (Leone et al., 2020; Walters et al., 2020). Despite this unprecedented situation, global and national food supply chains adapted relatively soon to the new situation, and empty grocery shelves widely disappeared after April 2020 (Aday and Aday, 2020; Leone et al., 2020). In the US, one of the reasons for this recovery was that $75 \%$ of agricultural commodities and food products are shipped on trucks which were able to respond flexibly to supply chain disruptions (Walters et al., 2020).

Farmers, horticulturalists, and meat producers, instead, were challenged throughout 2020 by decreased demand from hotels, restaurants, and charitable institutions (Nicola et al., 2020; Stephens et al., 2020). A further problem for food producers was a limited farmworker labor market due to travel regulation and visa measures, Meat production was most affected (Stephens et al., 2020; Torero, 2020). Similar challenges were faced by food processors: Due to decreased demand from restaurants, products needed to be adjusted (i.e., packaging sizes) for sales in grocery stores (Leone et al., 2020). Food supply chains dominated by a few large processors, such as meatpacking, were particularly vulnerable to their employees becoming sick (Hobbs, 2020; Stephens et al., 2020). By April 2020, 19 US states reported almost 5,000 COVID-19 cases and 20 deaths among 115 meat and poultry processing facilities and slaughterhouses, causing plants to close, or slow production (Dyal et al., 2020). Meat-processing volumes fell to 40\% below 2019 levels, and approximately 45,000 workers were affected by closures at meatprocessing plants (Laborde et al., 2020; Walters et al., 2020). To mitigate the challenges for food processors, the US Food and Drug Administration (FDA) issued interim guidelines in March 2020, simplifying rules for product labeling (Boyacı-Gündüz et al., 2021). Even though, the US food industry encountered a $23 \%$ sales drop in 2020, mainly due to restaurant closures (Nicola et al., 2020).

During the initial phase of the pandemic, most grocery stores remained open with adjustments, despite new information, and policies arriving almost daily. There was an initial lack of clarity on who should oversee the implementation of mitigation strategies (Aboelenien et al., 2021). Broken international, national, and regional supply chains in a food distribution system based on just-in-time manufacturing, delivery, and inventory management led to stocking difficulties up to empty store shelves and price increases of popular items (Walters et al., 2020). Further immediate challenges for food retailers involved missing frontline employees, protecting the health of their remaining employees, and lacking health supplies (masks, disinfectants). After the first chaotic weeks, stores managed to improve their safety standards, including food safety monitoring, and adapt their store layout to sanitation and safety requirements (Wang et al., 2020). Larger retailers with existing online ordering capability adapted soon to the increased demand for online orders, while smaller stores opted for completing phone orders or creating homespun website solutions (Leone et al., 2020). 
TABLE 2 | US consumer Food Price Index changes (index based on US\$) in March and April 2020 as compared to the respective previous month (US Bureau of Labor Statistics, 2021).

\begin{tabular}{lcc}
\hline US consumer food price index group & March 2020 & April 2020 \\
\hline Cereal and bakery & $+0.1 \%$ & $+3.1 \%$ \\
Dairy products & $+3.6 \%$ & $+5.2 \%$ \\
Meats, poultry, fish, and eggs & $+2.3 \%$, & $+6.8 \%$ \\
Fruits and vegetables & $-1.9 \%$ & $+0.4 \%$ \\
\hline
\end{tabular}

March and April 2020 were outstandingly profitable months for most food retailers (Pantano et al., 2020). National per capita food consumption of private households increased by $11 \%$ in 2020, with March 2020 sales 31\% beyond the March 2019 values and April 2020 sales 13\% above the previous year (US Census Bureau, 2021a). The strongest increases were observed for convenience food $(+24 \%)$, bread and cereal products $(+13 \%)$, and snacks (+12\%) (Statista, 2021). However, numerous non-traditional retailers (mobile markets, farmers' markets, community-supported agriculture) initially shut down their businesses due to food safety concerns. Accordingly, 74\% of farmer markets lost income in this phase (Feldman, 2020; Leone et al., 2020).

In 2019, about half of America's food dollars were designated to food prepared away-from-home. Because of the pandemic, between February and April of 2020 alone, monthly sales at foodservice and drinking places as well as at institutional food services (e.g., schools, hospital cafeterias) decreased by over $50 \%$. The forced closing of most of these venues shifted money directly to retailers. There was also a redirection in the workforce from food services to grocery stores (Leone et al., 2020; US Census Bureau, 2020a).

Regarding food retail prices, dairy, eggs, and meat product prices increased considerably in March 2020 and even stronger in April 2020 (Table 2). In April 2020, the cereal and bakery index saw the largest monthly price increase $(3.1 \%)$ ever recorded by the US Bureau of Labor Statistics (2021). In addition to higher prices, grocery store consumers received fewer promotions and discounts than usual (Leone et al., 2020). After the disruptions in March and April of 2020, price indices for most products remained stable above the 2019 levels, and some indices moderately decreased during the second half of 2020 (Johansson, 2020).

\section{Pandemic Intervention Authority in the US}

Pandemic intervention authority in the US, and specifically the governmental responses to the COVID-19 pandemic, have been characterized by interactions (and partially unclear authority competencies) between federal, state, tribal, and county authorities (Parmet and Sinha, 2020; Ren, 2020). Based on the Commerce Clause of the US Constitution, the federal government has superior authority to prevent the introduction, transmission, and spread of communicable diseases in the country (Cole, 2014; Blum, 2020). Accordingly, the federal government through the Centers for Disease Control and
Prevention (CDC) can, for example, isolate and quarantine individuals, but only if they are traveling between states (CDC, 2019, 2020a). Also, it was ruled that congress has the authority to regulate any activity that "substantially affects interstate commerce" (US Supreme Court, 2000). However, the US Constitution limits the role of the federal government and allows states to enact any measures that do not violate individual rights on their territories (Blum, 2020). Since 2017, the CDC has authority to take actions that are "reasonably necessary" if measures taken by states are considered inadequate. These competencies have been untested (Blum, 2020). Hence, the last time federal pandemic authority was fully enforced, was during the "Spanish Flu" pandemic in 1918 and 1919 (Gostin and Wiley, 2020).

As seen with COVID-19, the CDC de facto emphasized providing guidelines to states but did not require states to implement them (Blum, 2020). Instead, state, local, and tribal health authorities enforced their own pandemic laws. Hence, different from other countries, in the US, federal, state, local, and tribal health authorities can have and use simultaneously coexisting pandemic regulation and respective enforcement power (CDC, 2019, 2020a; Blum, 2020; Gostin and Wiley, 2020; Gostin et al., 2020). Consequently, during the COVID19 pandemic, the starting days, durations, and specific rules of pandemic regulations varied across the country (Hafiz et al., 2020; Taylor, 2020).

Concerning food retail, tribes, states, and local governments played significant roles in shaping the retail food environment, including creating food retail capacity and opening restrictions aimed at reducing the transmission of COVID-19 (Gostin and Wiley, 2020; Leone et al., 2020). During the first months of the pandemic, many authorities limited shopping access in their respective areas, for example by establishing shorter store hours that provided staff with more time for cleaning or by designated shopping times for vulnerable persons (Leone et al., 2020). At the federal level, the stimulus relief package of March 2020 involved support for food retailers, including the Paycheck Protection Program, a loan to help small businesses keep their workforce employed during the pandemic (Werner et al., 2020). A further core change was the inclusion of online purchasing (adopted by numerous states) in the USDA Supplemental Nutrition Assistance Program (SNAP), which supplements the food budgets of low-income households (Leone et al., 2020). Several states also supported federal nutrition assistance programs on home delivery programs for vulnerable populations, for example by covering delivery fees for SNAP online purchases (Leone et al., 2020; McLoughlin et al., 2020). In April 2020, the FDA released a "Best Practices during the Pandemic" document for food retail (US Food Drug Administration, 2020).

\section{Early Stage of the COVID-19 Pandemic in Montana}

Over a few days in mid-March 2020, everyday life in MT was transformed due to health regulations and individual responses to news about the COVID-19 pandemic (Nicola et al., 2020; Taylor, 2020). Retail, purchase, and consumption of food were 
immediately affected. Two regulations had the strongest impact on food sales and consumption in MT: (1) Montana State Directive Implementing Executive Orders 2-2020 and 3-2020 ("Stay at Home Directive"), providing measures for individuals and businesses and designating certain essential economic functions, published March 30, 2020 (State of Montana, 2020a) and (2) a state and federal State of Emergency (State of Montana, 2020d,e). These regulations expired on April 25, 2020, and were relaxed through a phased approach (State of Montana, 2020b).

Food stockpiling and panic buying across MT were immediate reactions to pandemic regulations (Taylor, 2020). A survey ( $n=$ 1944), conducted between April and September 2020, provides further insight into the impact of COVID-19 on the nutrition and health of Montanans. Accordingly, food access changed considerably: Although $74 \%$ of surveyed individuals increased cooking at home and $90 \%$ of them decreased eating out, $86 \%$ also decreased the frequency of leaving the house for groceries. The survey highlighted a negative effect of the pandemic on Montanans' health: Almost half of the surveyed persons indicated that they bought food out of fear or anxiety, 52\% increased snacking, $43 \%$ reported a weight gain, and 30\% increased their alcohol consumption (Byker-Shanks et al., 2021).

The implications of the pandemic for food security were also drastic. MT's food insecurity rate reached $15.5 \%$ by the end of 2020, a 51\% increase from 2019 (Lowrey, 2020; Montana Food Bank Network, 2020). The cost of preparing food at home in May 2020 was nearly 5\% higher than in May 2019 (Montana Budget Policy Center, 2020). Closures of public and charitable meal sites resulted in a lack of resources for MT's most vulnerable populations, especially in counties with high percentages of American Indian populations (Native Hope, 2020).

\section{Pandemic-Related Food Purchase Regulation in Gallatin County}

Apart from state regulation, the Gallatin County Health Department Emergency Health Rule relating to COVID-19 (EHR-2020-001, "State of Emergency") issued March 17, 2020, impacted food retail and consumption in the county (Gallatin County, 2020). It did not categorically limit consumer access to grocery stores, but stores were required to comply with social distancing guidelines, provide sanitizing products, and online and access information, as well as offer hours of operation exclusively for vulnerable populations (State of Montana, 2020c). Sit-down and dine-in food services, bars, and similar businesses were closed statewide for 9 days in late March 2020 but for a longer period in Gallatin County (Healthy Gallatin, 2020; Sherman, 2020). Due to regulations and policies enforced by managers, grocery store shopping changed drastically in March 2020 in Gallatin County, including shifted shopping hours with limitations for the general population, limited customer access to stores, remote shopping and curbside pickup, deli departments closed within stores, limited purchases for specific foods, no return policy, and mandatory behaviors for customers (social distancing) and employees such as the use of gloves and masks (MTN News, 2020).

\section{METHODS}

\section{Concept and Location}

For our case study, we conducted a (1) food and beverage sales data analysis (Timmons and Wang, 2010) of a highly frequented, independent grocery store in Bozeman, Gallatin County, MT, analyzing data of March and April 2019 (before the pandemic), as well as March and April 2020 (period of most severe lockdown measures in MT); and (2) semi-structured key informant interviews with the manager and one employee of the store where the sales data analysis was conducted, in addition to interviews with the manager and one employee from a second grocery store in Gallatin County. In our conclusions, we process data obtained in our case study (sales data analysis, key informant interviews) as well as findings from the literature review presented in the background section.

Gallatin County lies in Southwestern MT. In 2019, it had a population of over 114,000 , which makes it the third-most populated county in MT. White non-Hispanic persons made up for over $90 \%$ of the county population in 2018 . The median household income in 2018 was $\$ 61,500$, and over $50 \%$ of residents had a bachelor's degree or a higher educational level. Almost half of the residents live in the county seat, Bozeman, which has slightly lower income and higher education rates compared to the overall county (Data USA, 2021; US Census Bureau, 2021b). In 2019, there were 12 grocery stores in Gallatin County.

\section{Sales Data Analysis}

Grocery stores were defined as retail stores that contain a wide range of foods from all food groups, including fresh produce (Fuller et al., 2015). To assess the short-term effects of pandemic regulations on consumer food purchases, we acquired a deidentified data set from a popular grocery store in Bozeman, MT (Brinkerhoff et al., 2011). The store owners manage a single shop and are not aligned with national or regional chains. The data consisted of 10,784 food items, divided into seven categories according to store departments (Appendix 1). These items involved all food and beverage products sold in the store in at least one of the months March 2019, April 2019, March 2020, and April 2020. The data set comprising our sample included units of items sold per month, average monthly retail sales price per item, and average monthly purchase cost.

We used item descriptions to categorize all food items purchased into 14 categories (Fuller et al., 2015). Our categories were adapted from the food groups and subgroups of the 20152020 Dietary Guidelines for Americans (US Department of Health Human Services US Department of Agriculture, 2015). For vegetables, we used all five subgroups as separate categories: Dark-green vegetables, red and orange vegetables, legumes, starchy vegetables, and other vegetables. Grains (including flour, bread, and noodles), fruits (including 100\% fruit juice), and dairy (including dairy products such as butter) were processed as entire categories. Protein foods were divided into two categories: (a) Meat, fish (fresh and frozen), and eggs; and (b) processed meat. We added the categories snacks (including items such as crackers, potato and tortilla chips, roasted peanuts, milk chocolate, 
TABLE 3 | Food categories and subcategories applied in the processing of grocery store sales data, adapted from the 2015-2020 Dietary Guidelines for Americans (US Department of Health Human Services US Department of Agriculture, 2015)

\begin{tabular}{|c|c|}
\hline Category & Subcategory \\
\hline \multirow[t]{2}{*}{ Dark-green vegetables } & Fresh dark-green, vegetables \\
\hline & Frozen dark-green vegetables \\
\hline \multirow{2}{*}{$\begin{array}{l}\text { Red and orange } \\
\text { vegetables }\end{array}$} & Fresh red and orange vegetables \\
\hline & Canned red and orange vegetables \\
\hline \multirow[t]{2}{*}{ Legumes } & Dry legumes \\
\hline & Canned legumes \\
\hline \multirow[t]{3}{*}{ Starchy vegetables } & Fresh starchy vegetables \\
\hline & Canned and grocery starchy vegetables \\
\hline & $\begin{array}{l}\text { Frozen starchy vegetables (including } \\
\text { processed) }\end{array}$ \\
\hline \multirow[t]{2}{*}{ Other* vegetables } & Other fresh vegetables \\
\hline & Other frozen vegetables \\
\hline \multirow[t]{3}{*}{ Fruits } & Fresh fruits \\
\hline & Frozen fruits \\
\hline & Juice (100\%) \\
\hline \multirow[t]{2}{*}{ Grains } & Whole grains \\
\hline & Refined grains \\
\hline \multirow[t]{2}{*}{ Dairy } & Milk and plant-based milk beverages \\
\hline & Other dairy products \\
\hline \multirow{4}{*}{$\begin{array}{l}\text { Meat, fish, eggs (fresh } \\
\text { and frozen) }\end{array}$} & Beef \\
\hline & Chicken \\
\hline & Pork \\
\hline & Chicken eggs \\
\hline \multirow[t]{3}{*}{ Processed meat } & Ham and bacon \\
\hline & Sausage \\
\hline & Cold cuts \\
\hline \multirow[t]{2}{*}{ Snacks } & Salty snacks \\
\hline & Sweet snacks \\
\hline \multirow{2}{*}{$\begin{array}{l}\text { Convenience and other } \\
\text { processed food }\end{array}$} & Frozen convenience food \\
\hline & Othe processed food \\
\hline \multirow[t]{3}{*}{ Alcoholic beverages ${ }^{\star \star}$} & Beer \\
\hline & Wine \\
\hline & Other alcohol \\
\hline \multirow{3}{*}{$\begin{array}{l}\text { Non-alcoholic } \\
\text { beverages }\end{array}$} & Soda \\
\hline & Water \\
\hline & Other beverages \\
\hline
\end{tabular}

*Vegetables not classified as dark-green, red and orange, starchy vegetables, or legumes (including, for example, onion, cucumber, or parsley).

${ }^{\star \star}$ Liquor not sold.

cookies, and ice cream) and convenience food (processed multiingredient items that require little preparation for consumption as a meal, including frozen pizza, instant noodles, and waffles). We used two hierarchical levels to organize items (Table 3). The top tier in this hierarchy was the aforementioned categories, the second level subcategories such as dry vs. canned legumes.
The items were classified by a generic name (for example, fresh spinach), the respective brand name, the sales presentation (for example, bottle or can), and sales dimension (for example, 5 oz., see Appendix 2). We assessed the average monthly number of items sold for each item over the 4 studied months and selected the eight most sold products per category for further data processing, resulting in 112 food and beverage items (Appendix 2).

Our primary analysis focused on changes in food purchases comparing average data from March and April 2019 with the average purchases in March and April 2020 for individual items and food groups. Where applicable, we compared items belonging to different subcategories within a category, for example fresh versus frozen spinach. We also analyzed acquisition costs for the grocery store and compared them with sales prices to calculate profits per item. Outcome variables included the total monthly purchase cost per item (number of items purchased multiplied by item cost in US\$), total monthly retail sales per item (number of items purchased multiplied by item sales price in US\$), profit (total monthly retail sales minus total monthly purchase cost per item in US\$), and calories of items sold (number of items purchased multiplied by the nutritional value of each item in Kcal). If available, nutritional values were obtained from the calorie amount per serving disclosed on the Nutrition Facts Label specified by the FDA and the US Department of Agriculture (USDA). Calories per item were adjusted to the sales unit (number, weight, or volume) of the respective item (Metzger, 2010). Where nutrition labels were unavailable (mainly produce), we obtained nutritional value data from the USDA Food Data Central database (US Department of Agriculture, 2021).

Statistical analyses of sales data were conducted using SPSS for Windows, v 26 (IBM, Armonk, NY) (De Sá, 2007). We assessed distributional and other model assumptions prior to their applications to select appropriate methods for categorical responses. For the analysis of the normality of distribution of differences of our outcome variables between two related groups (March and April of 2019 versus the same months of 2020), we used the Shapiro-Wilk normality test and QQ plots to detect potential significant outliers in the differences between these groups (Hedberg and Ayers, 2015). We found that for all analyses between related groups (in our case, purchases of one item at two time points), statistical models relying on normality were reasonable for processing our primary outcome. We then used paired samples $t$-Test at $p<0.05$ to compare the means of sales data from two related samples (Ross and Willson, 2017) for the assessment of consumer purchase changes per category and item. Inter-associations within a category were assessed using twosided Fishers Exact Test at $p<0.05$ (Upton, 1992). Variable labels in charts were occasionally abbreviated to increase readability. Accordingly, "Meat and eggs" in Figures 1-4 represents the category "Meat, poultry, fish, and eggs."

\section{Semi-Structured Interviews}

We conducted four semi-structured interviews with each, the manager and one experienced employee of two grocery 


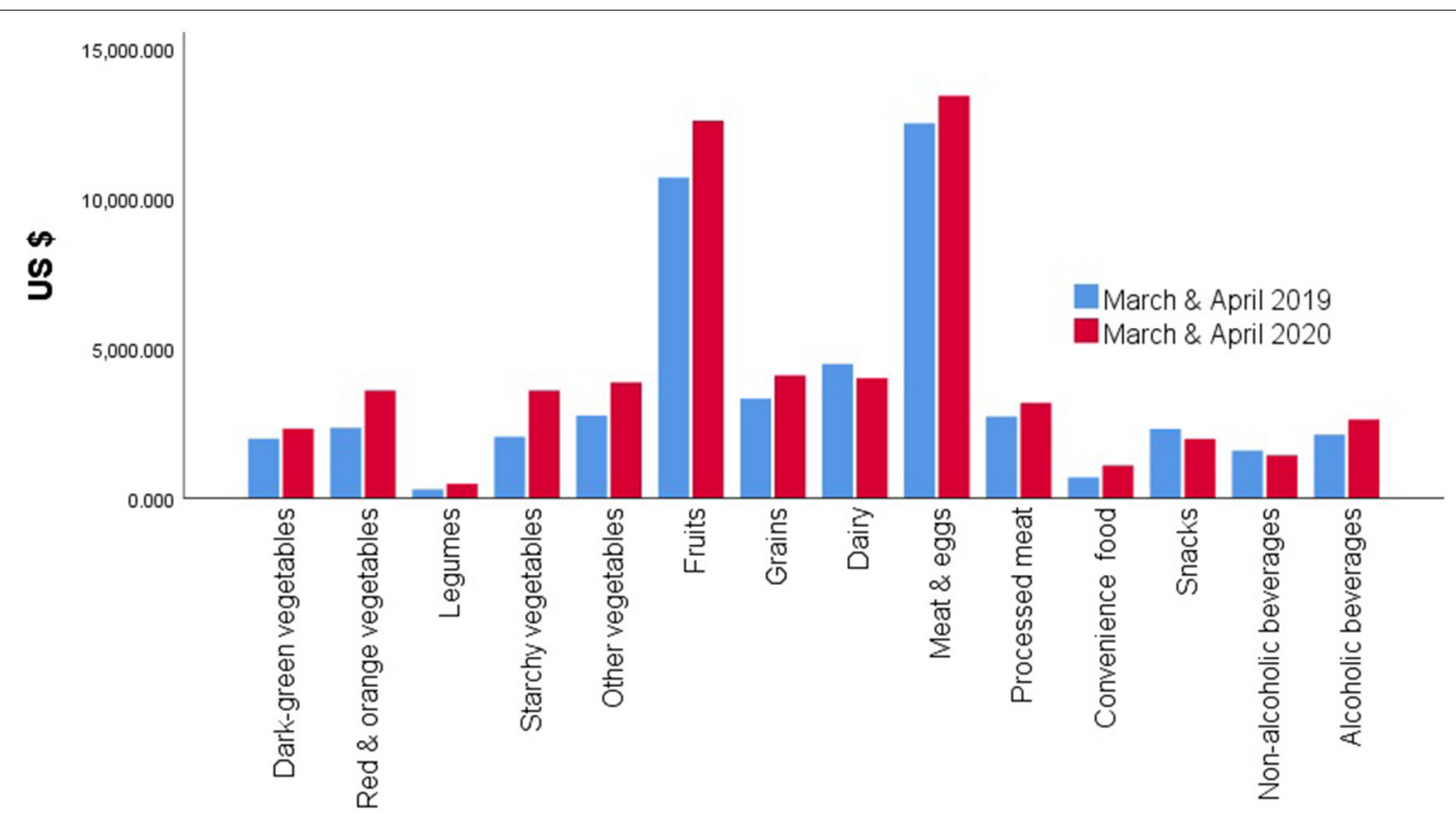

FIGURE 1 | Average monthly sales per food category in nominal US $\$$ values $(p<0.01) .3 .2 \%$ Consumer Food Price Index increase between April 2019 and April 2020 (US Bureau of Labor Statistics, 2021).

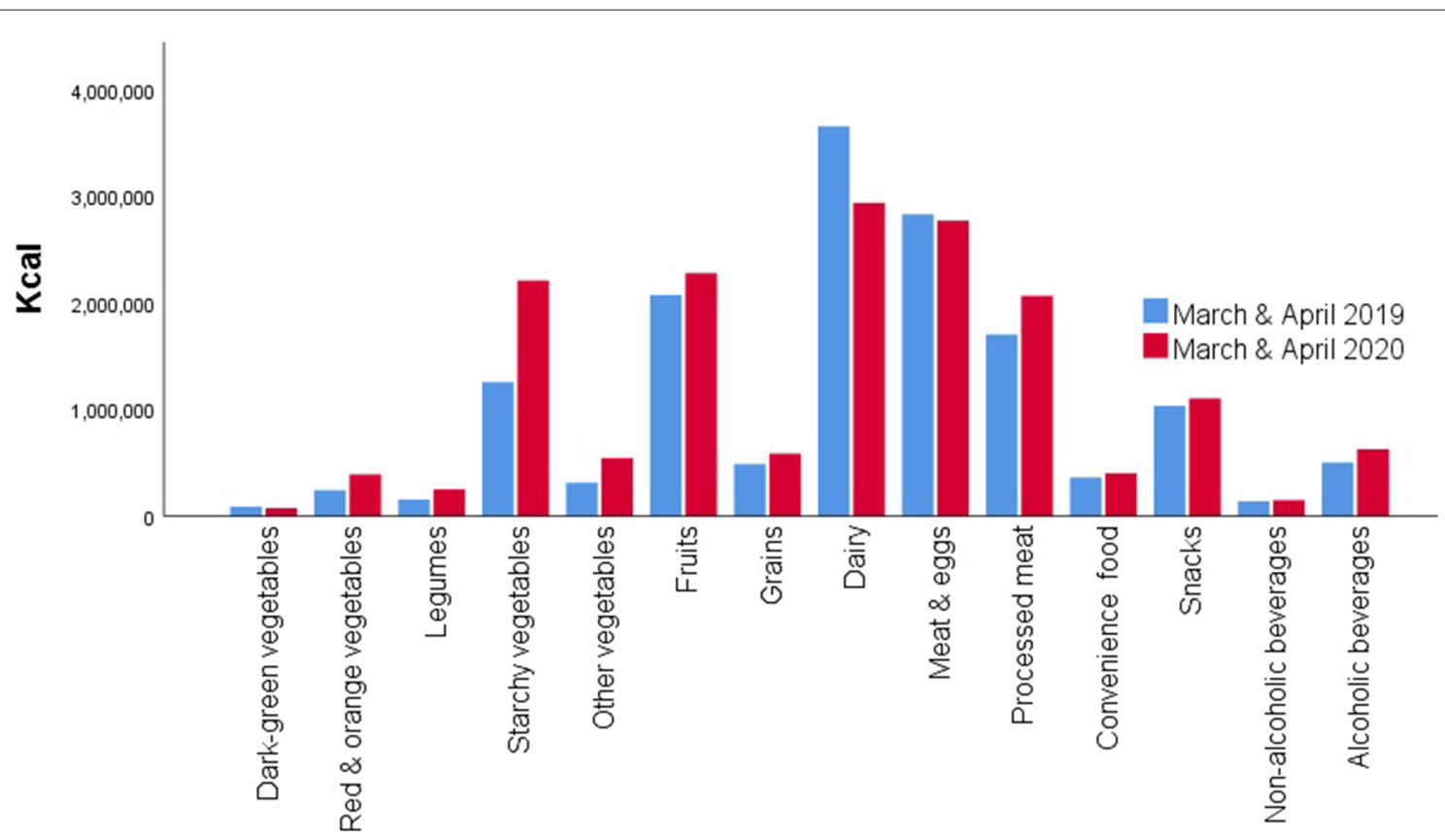

FIGURE 2 | Average monthly caloric value of sold items per food category in Kcal, comparing average total monthly caloric values of eight items per food category in March and April 2019 and March and April 2020 ( $p=0.26$ ).

stores in Gallatin County: the store in Bozeman, MT, where we implemented the sales data analysis and a store, and a grocery store in nearby Belgrade, MT, which belongs to a small local chain comprised of six stores in Southwestern MT.
The development of the interview questionnaire was informed by the following overall research question: How did the COVID19 pandemic and associated local and state regulatory measures impact consumer food purchases in Gallatin County, the economy of local grocery stores, and the wellbeing of grocery store employees? 


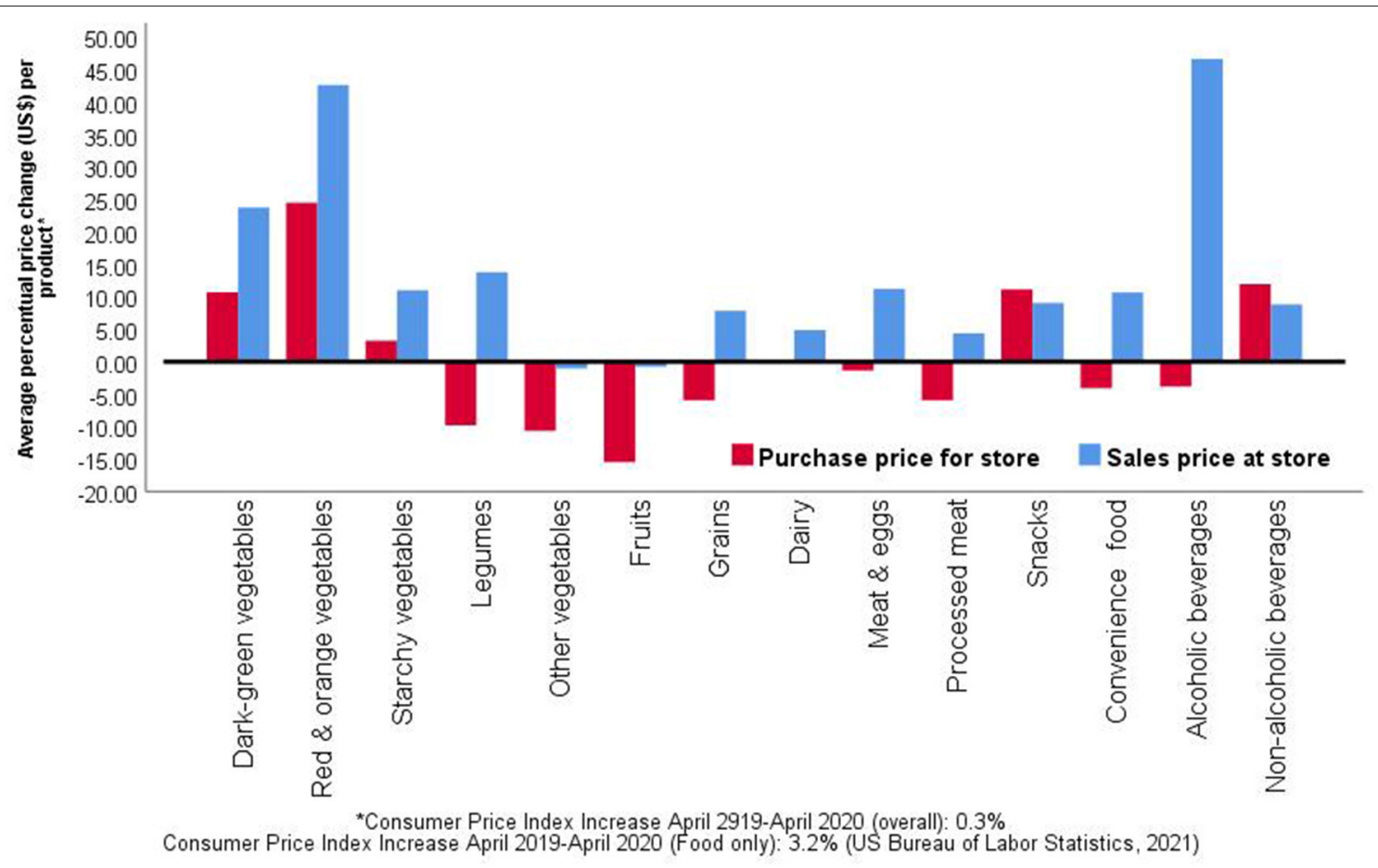

FIGURE 3 | Average monthly purchase price for store and sales price for customers (in nominal US\$) changes, comparing average monthly actual price in- and decreases in March and April 2019 and March and April 2020 ( $p=0.01$ ).

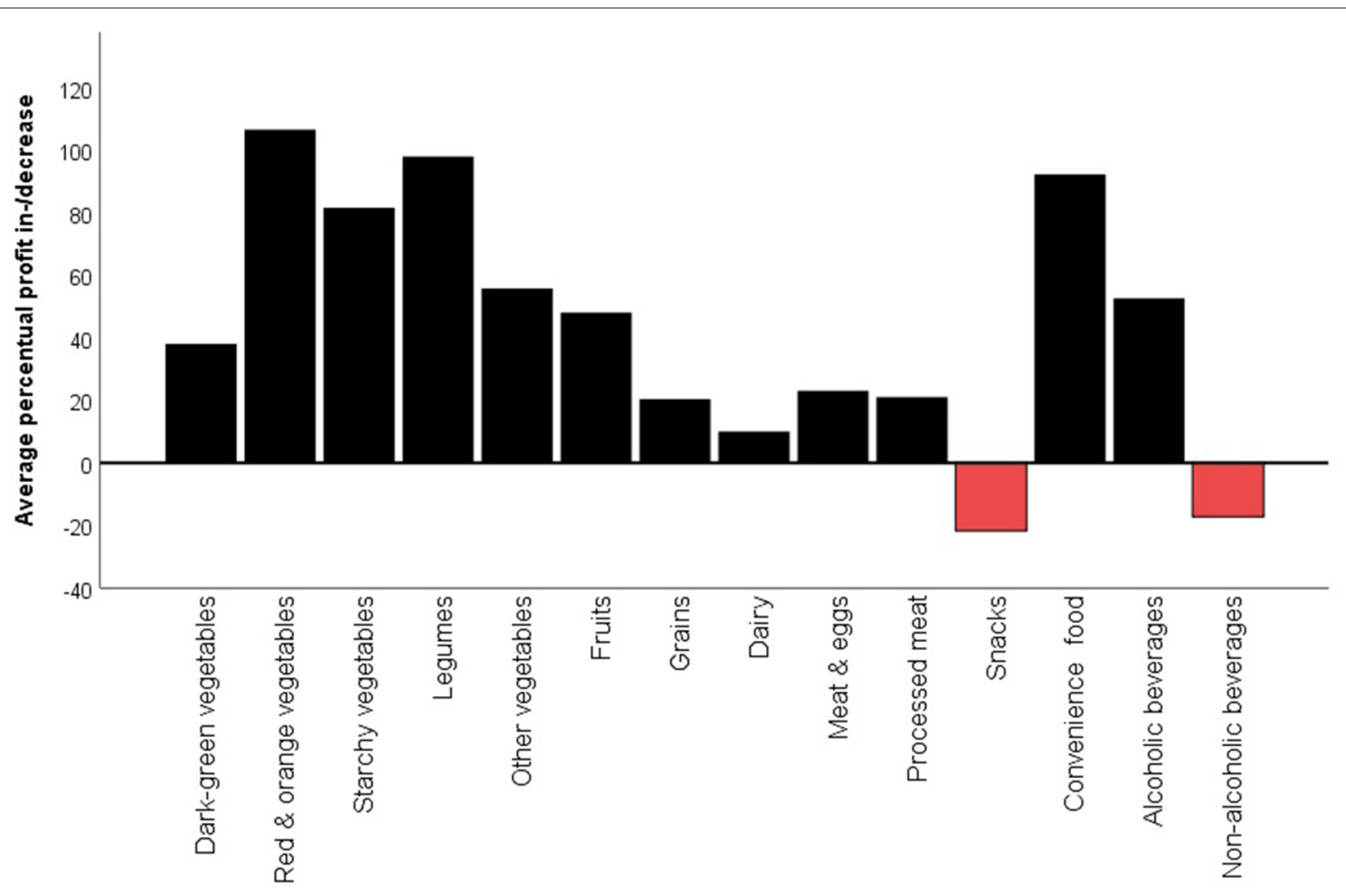

FIGURE 4 | Percent changes in average monthly grocery store profits per food category, comparing March and April 2019 and March and April 2020 ( 0 = 0.02 ) in nominal US\$ values. 3.2\% Consumer Food Price Index increase between April 2019 and April 2020 (US Bureau of Labor Statistics, 2021 ). 
We developed 13 research questions, 12 of which were asked managers, and 11 of which employees (Appendix 3).

After designing the questionnaire and prior informed consent form for Institutional Review Board (IRB) approval for the participation of human subjects at Montana State University, we received approval in January 2021 (IRB approval number RE012121-EX). Participation in interviews was voluntary, with prior informed consent obtained from all participants. During the first minutes of each interview, we presented the aims and procedures of the interview including the anonymity and confidentiality of responses, inclusion criteria, and contact details of the research team and Institutional Review Board. Interviews were conducted in January 2021 and lasted $20-35 \mathrm{~min}$ per interviewee.

In May 2021, we conducted a data validation interview (Buchbinder, 2010) with the manager of the store whose data flew into the sales data analysis (this individual was also interviewed) to obtain feedback on the accuracy of our findings and discuss the most significant outcomes.

For all interview analyses, we conducted inductive, undirected content analysis to identify common themes in responses (Kuckartz, 2014; Saldaña, 2015). Our coding process was facilitated by the qualitative software NVivo 12 (QSR International, Doncaster, Australia). We applied inductive coding to identify key variables as preliminary coding categories, resumed all condensed meaning units, and calculated the frequency of meaning units per code as a percentage of total meaning units per question (Leech and Onwuegbuzie, 2011; Saldaña, 2015).

\section{RESULTS}

\section{Sales Data Analysis}

We observed significant increases in purchases of most food categories, outstandingly of starchy vegetables, legumes, convenience food, as well as red and orange vegetables, where purchases increased by more than $50 \%$. In change, purchases of non-alcoholic beverages, dairy, and snacks decreased (Table 4). Figure 1 details that net sales increased greatest for fruits, followed by starchy vegetables, red and orange vegetables, and meat and eggs.

In terms of caloric value per food category, the strongest relative increases by trend occurred for starchy, followed by "other," red and orange vegetables, and legumes, with increases beyond $60 \%$. The highest relative decreases were observed for dairy (Table 5). The strongest absolute caloric value increases by trend occurred for starchy vegetables, processed meat, and "other vegetables", while dairy saw the highest decrease (Figure 2).

Figure 3 highlights that, while purchase prices for the analyzed grocery store increased most for red and orange vegetables (24.5\%), non-alcoholic beverages (11.97\%), and snacks (11.14\%), the strongest purchase price decreases occurred for fruits $(-15.5 \%)$, "other" vegetables $(-10.68 \%)$, and legumes $(-9.81 \%)$. US food prices increased by $3.2 \%$ between April 2019 and April 2020 (US Bureau of Labor Statistics, 2021). However, Figure 3 shows that sales prices in all categories except for fruits and "other" vegetables increased beyond this value, with the
TABLE 4 | Increases in customer food purchases per food category (index based on nominal US\$ sales prices), comparing average monthly purchases in March and April 2019 and March and April 2020 ( $p<0.01)$.

\begin{tabular}{lc}
\hline Food category & Percent purchase increases 2019-2020 \\
\hline Starchy vegetables & $74.84 \%$ \\
Legumes & $61.49 \%$ \\
Convenience food & $56.91 \%$ \\
Red and orange vegetables & $52.89 \%$ \\
Other vegetables & $40.08 \%$ \\
Alcoholic beverages & $23.69 \%$ \\
Grains & $23.38 \%$ \\
Fruits & $17.76 \%$ \\
Processed meat & $16.86 \%$ \\
Dark-green vegetables & $16.73 \%$ \\
Meat and eggs & $7.34 \%$ \\
Non-alcoholic beverages & $-9.97 \%$ \\
Dairy & $-10.65 \%$ \\
Snacks & $-14.26 \%$ \\
\hline
\end{tabular}

3.2\% Consumer Food Price Index increase between April 2019 and April 2020 (US Bureau of Labor Statistics, 2021).

TABLE 5 | Percent increases in caloric value of customer food purchases per food category (in Kcal), comparing average monthly purchases in March and April 2019 and March and April 2020 ( $p=0.26$ ).

Food category

Percent purchase increases 2019-2020

Starchy vegetables

$75.87 \%$

Other vegetables

$72.66 \%$

Red and orange vegetables

$61.05 \%$

Legumes

$60.01 \%$

Alcoholic beverages

$24.53 \%$

Processed meat

$21.2 \%$

Grains

$19.71 \%$

Convenience food

$10.58 \%$

Fruits

$9.9 \%$

Snacks

$6.64 \%$

Non-alcoholic beverages

$6.22 \%$

Meat and eggs

Dark-green vegetables

$-2.11 \%$

Dairy

$-14.69 \%$

$-19.66 \%$

strongest increases for alcoholic beverages (46.69\%), red and orange vegetables (42.65\%), and dark-green vegetables (23.77\%).

Comparing the months of March and April 2019 to the same months of 2020, Figure 4 shows that the analyzed grocery store saw increased profits in all food categories, except for snacks $(-21.73 \%)$ and non-alcoholic beverages $(-17.24 \%)$. The strongest profit increases were observed for red and orange vegetables (106.57\%), legumes (97.96\%), and convenience food (92.27\%).

Regarding purchases of individual products, highest percent increases per trend $(p=0.44)$ were observed for romaine, canned carrots, and peas, as well as frozen green beans (Appendix 4). We 
detected highest percent decreases by trend for roast beef, Swiss cheese, and fresh corn (Appendix 5).

Comparing customer purchase changes between 2019 and 2020 for pairs of fresh and frozen vegetables, we found a trend to a stronger increase of frozen broccoli and spinach purchases, while fresh spinach purchases only increased slightly, and fresh broccoli purchases even decreased. Contrastingly, purchases of fresh carrots increased stronger by trend than of frozen carrots (Figure 5). Comparing dried and canned legumes, purchase increases were stronger by trend for dried black and kidney beans, while as for white beans, customers increased their spending more on canned products (Figure 6).

\section{Semi-Structured Interviews}

All four interviewed persons (two grocery store cashiers, two managers) noticed a changed behavior of their customers during the lockdown. They all detected "panic," "fear," and "uncertainty" within their clients. "You could see the fear in their eyes,", described one manager customers. Three interviewees mentioned "customers' rushing through the store" as the most visible change, or as one manager put it: "People were on a mission." Conflicts were generated through reluctance to social distancing. "Some became very agitated if others came too close," stated one cashier. "People wanted to scan their items themselves so that I would not touch them," added another cashier.

Excessive hoarding was observed by three interviewees. One cashier stated: "The most similar thing I had ever seen was during a Hurricane in Georgia. Shelves were wiped out." This cashier remembered that "One morning, a man came in, wanting to return three bottles of an analgesic, of which we had bought eight the day before. The man claimed that he had no explanation why he had bought everything left on the shelves but thought he could not be without these bottles. Now, he wanted to return some for others". Both cashiers also have good memories. "Most people were appreciative," said one. "Many customers gave me tips," stated the other. While both managers acknowledged that changed customer behavior was influenced by regulation measures, both cashiers related it more to "individual panic."

There was agreement that the first weeks of the lockdown were extremely stressful for grocery store personnel, especially because of the customers' behavior. "We were not scared of the virus but of how people were acting," articulated one manager who worked over $80 \mathrm{~h}$ a week during the initial stage of the pandemic. One cashier was more concerned about getting sick: "I am in my early 60 s and wasn't sure if I should be working."

All interviewees found that customers "did not tighten their belts" because of the economic consequences of the pandemic, quite the contrary: "It was as if money didn't matter," said a cashier. "Customers did not aim for more healthy or unhealthy food, they just wanted food," specified a manager. "A mother and a son came in 3 days straight and bought over $\$ 600$ of groceries.", remembered a cashier.

There was general satisfaction with state and county pandemic legislation. Of all regulatory measures, mask mandates (statewide introduced in July 2020, but strongly recommended at both stores since April 2020) were unanimously considered to have had the strongest impact on customer behavior. "I got very nervous when someone came in and refused to put on a mask," said one cashier. "Customers were horrible and would attack us verbally abusive," added the other one. One manager remembered that quarantines were also difficult to deal with: "At one point, we were down at $25 \%$ of our staff."

Asked about consumer purchases of different food groups, interviewees agreed that "demand for almost everything increased." Three out of four interviewees mentioned alcohol, dairy, and eggs, as well as vegetables as the most demanded food groups. "Consumers first took fresh vegetables and once they were gone, they purchased frozen and canned vegetables," specified one manager. Three out of four interviewees related increased alcohol purchases to closures of restaurants and public kitchens. As for specific products, "anything shelf-stable was bought up right away." All four interviewees stated rice, canned soups, and canned beans as most demanded specific products, followed by noodles and milk.

Regarding the supply chain, both managers agreed that they had difficulties to "keep up with demand." While produce was relatively easy to purchase, buying canned foods, baking products, and dairy was most challenging, according to the managers. Both called the lockdown a highly profitable period for their store. One manager added that online orders in their store increased more than tenfold during the lockdown. Following this manager, another positive side-effect of the pandemic legislation was that "as restaurants closed, I gained some very talented people."

\section{DISCUSSION}

\section{Study Goal, Environment, and Limitations}

Our case study focused on the impact of COVID-19 legislation and individual customer perceptions on grocery store food purchases in Gallatin County, MT, during the initial months of the pandemic. We used sales data analysis and semistructured interviews to assess consumers' alignment with the Dietary Guidelines for Americans 2020 before versus during the pandemic. Secondly, we aimed to learn about food system influences, specifically how the pandemic affected local grocery stores and the working conditions of their employees. Therefore, we selected 112 food products of a grocery store in Bozeman, Gallatin County, MT, and analyzed respective food purchases in March and April 2019 (pre-COVID) and March and April 2020 (most severe pandemic regulation measures in MT). Additionally, we conducted semi-structured interviews with managers and employees of two grocery stores in Gallatin County.

We were particularly interested in the impact of pandemic regulation (including governmental and store policies) on food purchases during the first months of the pandemic. However, we were aware that behavioral change of food consumers during such a crisis is equally impacted by further exogenous (for example, economic developments, job market, supply chains, working environments, or media coverage) and endogenous factors, including risk perception and health of the consumers (Wen et al., 2005; Sterman and Dogan, 2015; Chaganti et al., 2020; Hafiz et al., 2020; Power et al., 2020; Roe et al., 2021). 


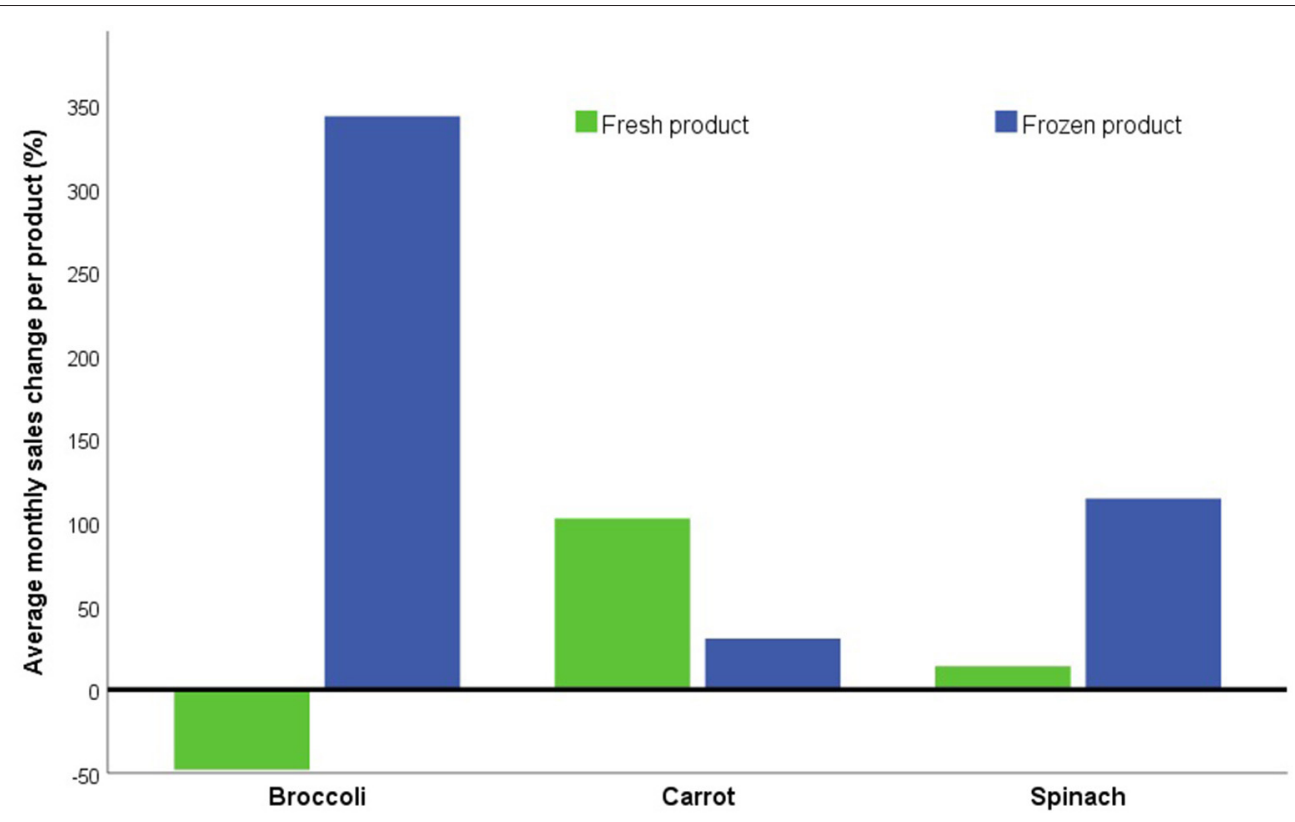

FIGURE 5 | Percent changes in average monthly customer purchases of selected pairs of fresh and frozen vegetables, comparing March and April 2019 and March and April $2020(p=0.18)$ in nominal US \$ values. 3.2\% Consumer Food Price Index increase between April 2019 and April 2020 (US Bureau of Labor Statistics, 2021).

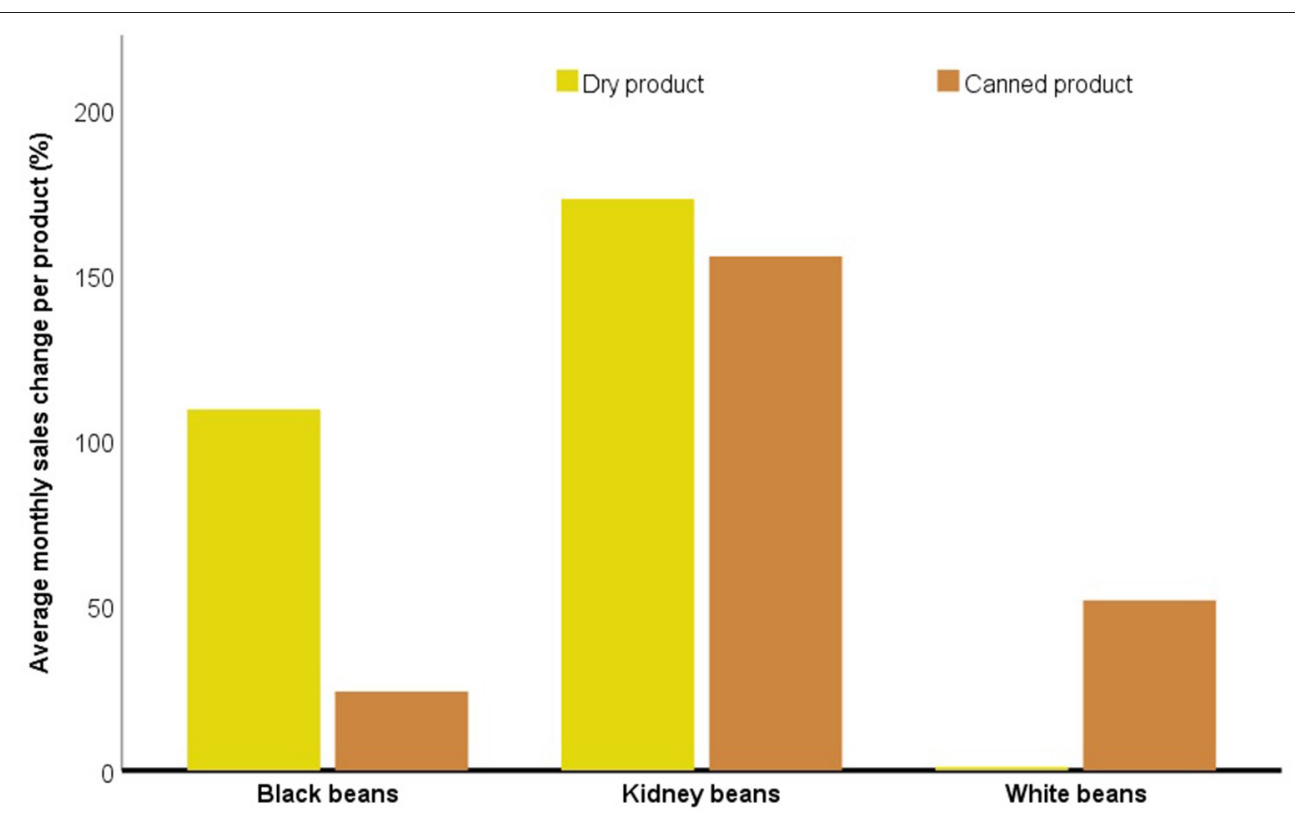

FIGURE 6 | Percent changes in average monthly customer purchases (in US\$) of selected pairs of dry and canned legumes, comparing March and April 2019 and March and April $2020(p=0.7)$ in nominal US\$ values. 3.2\% Consumer Food Price Index increase between April 2019 and April 2020 (US Bureau of Labor Statistics, 2021).

Results of our sales data analysis must be seen in the context of the peculiarities of its environment: Although the median annual household income in Bozeman of $\$ 61,500$ is below the median US income of $\$ 68,700$, it is above the median income in MT of $\$ 54,970$ (all data from 2019), which makes Bozeman an economically privileged place within this state
(US Census Bureau, 2021b). This may explain why most grocery store customers in our study "did not tighten their belts" during the lockdown (as one cashier stated in the interviews), despite a national economic crisis caused by the pandemic, triggering unemployment, and decreasing food security (Nicola et al., 2020; Sharif et al., 2020). Additionally, with $50 \%$ of residents having 
at least a bachelor's degree, the educational level in Bozeman is higher than statewide, where this number is $32 \%$ (Data USA, 2021; US Census Bureau, 2021b). Formal education impacts food choices considerably, especially regarding the healthiness of purchased food (Kamphuis et al., 2015).

Not all customers had the financial resources to respond to the pandemic. Triggered by COVID-19, in 2020, food insecurity or lack of access to affordable and nutritious food spiked from 11 to 28\% US-wide (Schanzenbach and Pitts, 2020; US Department of Agriculture, 2020). Recommendations to shift consumer behavior were difficult for most individuals, but less achievable for individuals facing food insecurity (Byker-Shanks et al., 2020b, 2021). To mitigate the harmful effects of food insecurity on US households during the pandemic, the USDA expanded benefits and introduced flexibilities to federal nutrition assistance, such as the SNAP program. It is unknown whether and to which extent the observations in this case study apply to food secure or food insecure audiences and how the expansion of SNAP benefits may have contributed to unusual food purchases. Future research should explore the impact of increased nutrition assistance benefits on consumer behavior overall.

Our case study dealt primarily with implications of state, county, and store policies. In 2020, the US encountered a mosaic of differing legislations due to the relative weakness of the federal pandemic authority (Cole, 2014; Hall et al., 2020), which impeded a concerted national response to a global pandemic. The question remains whether a more uniform national policy would ameliorate some of the disorganizations observed during the first months of the pandemic (in- and outside the food system), while still allowing the US to maintain its federal nature (Blum, 2020). Our case study was not designed to answer this question, but its outcomes must be understood in the context of regulations for MT and Gallatin County, which were widely congruent with policies in other states and counties. Thus, our findings have extensive but not universal validity for the entire US.

\section{Impact of COVID-19 Pandemic on Grocery Store Consumer Food Choices}

We based our case study on the hypothesis that grocery store food purchases in Gallatin County would have changed significantly during the COVID-19 crisis. Comparing sales data from the same months in 2019 and 2020, we found that food purchases increased in 11 out of 14 analyzed food categories, including increases above $60 \%$ in four categories. These data suggest that the impact of the pandemic on grocery food sales in Gallatin County was aligned with developments in other parts of the US (DeBroff, 2020; Chenarides et al., 2021).

In our case study, we detected two notable trends in consumer food choices: First, sales increased for food products with a longer shelf-life (Table 4). Greater increases were observed across starchy vegetables and legumes, which have a long shelf-life, than for green and red vegetables, which tend to have a shorter shelf-life (Figure 1). Customers emphasized fresh produce but opted for frozen vegetables if fresh ones were not available due to supply chain shortages (interviews). Within green vegetables, sales increased more for frozen than for fresh ones (Figure 5).
Processed meat sales increased more than fresh meat sales. Sales of convenience foods (for example, canned soups) and grains (especially rice and noodles), which are both shelf-stable, increased greatly (Figures 1, 6; interviews). Second, sales of specific food products that require preparation at home (for example, grains and tomato paste) increased, or "anything shelf-stable was bought up right away" as a cashier stated it. This finding is congruent with a MT-wide study, where $74 \%$ of respondents indicated that they increased cooking at home (Byker-Shanks et al., 2021). Alternatively, sales of snacks, water, and sparkling which do not require preparation at home, decreased (Table 4). As indicated by one store manager, (natural and sparkling) water is often purchased in small containers for the ride home or the office. Since $86 \%$ of Montanans decreased leaving the house for groceries during the lockdown (Byker-Shanks et al., 2021), such spontaneous purchases were certainly affected by the pandemic. Overall, our observed trends follow documented consumer behavior changes to stock up on foods in response to perceived risk and government regulations (Timmer, 2012; Kirk and Rifkin, 2020; Aboelenien et al., 2021).

Additionally, consumers made food choices that reflected they were forced to cook more, may have had more time for meal preparation, and had easier access to the kitchen when working and schooling from home. For example, customers purchased dry legumes at astounding rates compared to pre-pandemic and may have used more tap than bottled water due to proximity to a sink (Table 4; Appendix 5). These trends in food preparation likely impacted women in households with children greater than men, given their typical responsibility for meal preparation (Wolfson et al., 2021).

Changes in sales influence human health when the food purchased is consumed (Monteiro et al., 2013). Assessing the amounts of calories sold has the potential to provide insight into eventual impacts on human health. The strongest increase in calorie sales was observed for starchy food and several grain products (Table 5; Figure 2; interviews). Further, convenience foods and processed meat, especially instant ramen noodles, smoked ham, canned chili con carne, and instant noodles increased greatly (Appendix 4). Many of these foods, which are ultra-processed and high in refined grains, saturated fat, added sugars, and sodium, have the potential to influence weight gain and subsequent chronic disease development if eaten in higher amounts on a long-term basis. In fact, 6 in 10 adults in the US report undesired weight changes since the beginning of the pandemic (American Psychological Association, 2021). These findings should be assessed in light of the impact of restaurant and bar closures. For example, calories of alcohol sold at the grocery store increased, but some increase is expected to be caused by the closure of all bars in Gallatin County.

\section{Drivers of Consumer Food Choices}

The analysis of our semi-structured interviews with grocery store managers and employees indicated that endogenous causes, especially individual panic triggering hoarding and excessive buying, had a stronger impact on consumer food choices and 
behavior than pandemic regulation. We found in our interviews that panic buying and hoarding not only caused excessive spending on food but also indifference regarding food choices: "Customers did not aim for more healthy or unhealthy food, they just wanted food," as a manager stated. Similar consumer disregard of food price and quality during the pandemic was observed across the US and reveals the tradeoffs households are willing to make in times of (perceived or actual) scarcity and crisis (Ellison et al., 2021).

Related to individual panic, we identified "rushing" as a further significant determinant of consumer food purchases. Our interviewees concordantly noted that grocery store customers spent less time in the stores and frequented them less than before the pandemic but simultaneously purchased more food than usual. "People were on a mission," commented one cashier. This is congruent with findings of similar studies in the US, whereby the majority of US food consumers decreased store visits (Chenarides et al., 2021) and length of stay in stores (Wang et al., 2020) but spent more money on food than pre-pandemic (DeBroff, 2020). It is likely that consumers' hasting through the stores impacted their food choices and contributed to the observed indifference regarding food properties. Noteworthily, Goolsbee and Syverson (2021) discovered that legal restrictions were only responsible for a fraction of the decrease in consumer traffic in US stores during the first months of the pandemic and that endogenous factors, especially panic, were the core drivers of consumer "rushing."

Despite the detected prevalence of endogenous stimuli for food choices of grocery store customers, the semi-structured interviews highlighted that pandemic regulation (at different governmental levels), placed to suppress the spread of the virus and mitigate the pressure of the disease on the public health system, also had a considerable impact. However, there is overlapping between endogenous and exogenous causes of consumer responses to crises as policies of the last decades emphasized the role of consumers (rather than of the government) to protect themselves and their environment against a threat like COVID-19, a development known as "responsibilization" (Giesler and Thompson, 2016).

Still, we determined three triggers of consumer food choices and behavior in our study which can we attribute to exogenous causes. (1) Due to interrupted supply chains during the lockdown period, stores "had difficulties to keep up with demand for certain products," as both store managers noted. This was remarkably the case for dairy products, where the decrease in purchases (Figure 1) was "more related to supply shortages, especially in March 2020, than to decreases in demand" (store manager at validation interview). Exogenous drivers also affected consumer demand and behavior in stores: Pandemic regulations caused a shift of food dollars from restaurants and public kitchens to food retailers (Hobbs, 2020; Pantano et al., 2020; Ellison et al., 2021). (3) Mask mandates were identified as the legal measures with the strongest impact on the work routine in food retail. As numerous customers refused to follow these mandates and some of them reacted aggressively to respective requests of store personnel, workers "feared for their safety."

\section{Impact of COVID-19 Pandemic on Grocery Store Workforce and Economy}

Not only customer behavior made the first months of the pandemic an extremely stressful time for store employees and managers. We found that workloads were also far beyond usual. This was caused by increased consumer demand, supply chain issues, and decreased availability of labor due to quarantines. "At one point, we were down at $25 \%$ of our staff," stated one manager. Similar workforce availability disruptions were observed across the US food supply chain (Luckstead et al., 2021). However, grocery stores were able to recruit experienced employees from restaurants.

Purchase of food from several categories became more expensive for stores (especially, red and orange vegetables, darkgreen vegetables, non-alcoholic beverages, and snacks), while wholesale of other categories (fruits, grains, legumes, and "other vegetables") became less expensive. Thus, store sales prices increased in most food categories, notably for dark-green as well as red and orange vegetables and alcohol (Figure 3). Accordingly, food price indices also increased nationally during March and April 2020, especially for dairy products, meats, poultry fish, and eggs (US Bureau of Labor Statistics, 2021). One store manager indicated in the validation interview that the observed purchase price changes were not necessarily related to the pandemic but mainly due to shortages and other specific circumstances in the control months of March of April 2019. The store manager asserted that "it was not the store's policy to increase prices to benefit from the pandemic." However, Figure 4 highlights that the initial phase of the pandemic was a profitable time for the store, as it was for food retail US-wide (Ellison et al., 2021).

\section{LIMITATIONS}

Given that the (1) quantitative data were obtained from one single grocery store, (2) only four individuals from two stores were interviewed for the qualitative section, and that (3) Bozeman (being a college town) is not representative for all urban areas in Montana or the Northwestern US, our research resembles a case study. Consequently, the significance and generalizability of our outcomes and the global conclusions we draw from them must be interpreted in the context of the small sample size of our study, including potential biases.

\section{CONCLUSIONS}

The objective of our case study was to understand how food consumption patterns and food purchase behavior changed during the initial months of the pandemic in order to enhance pandemic regulation with limited negative externalities for food consumers, especially for their nutrition. The significance of such policies goes far beyond nutrition: Effective pandemic regulations can help mitigate the negative socio-economic consequences of a health crisis. Access to affordable and healthy food during a pandemic also decreases public spending on healthcare due to a reduced risk of nutrition-related NCDs such as diabetes and obesity and thanks to a functioning immune system that 
helps decrease fatal health outcomes of diseases like COVID19 (Samartin and Chandra, 2001). As observed in our study, pandemic regulation and other exogenous factors strongly impacted the emotional wellbeing of store employees and the economy of food retailers.

We learned that consumer choices and behavior were widely caused by endogenous factors, including individual panic. Although regulations will never be capable of controlling all consumer responses, functional policies can impact the risk perceptions of consumers and may decrease unreasonable stockpiling, hoarding, and panic buying. Based on our findings and the emerging external data on this topic (resumed in our literature review), we convey a series of suggestions to be considered in future pandemic legislation, including the following:

- Development of programs to prevent excessive customer spending, hoarding, and panic buying in times of pandemics and similar crises, including educational programs and information policies (see sections Semi-Structured Interviews, Impact of COVID-19 Pandemic on Grocery Store Consumer Food Choices; Table 5).

- Educational programs that train households in food resource management, including stockpiling plans, and appropriate food purchase choices in cases of (perceived or real) food shortages (see sections US Consumer Responses to the COVID-19 Pandemic, Semi-Structured Interviews, Drivers of Consumer Food Choices).

- Household training in the selection and preparation of nutritious meals with shelf-stable ingredients, which can be high in added sugars, sodium, saturated fat, and additives (see section Drivers of Consumer Food Choices; Figures 2, 5, 6; Appendix 4).

- Use of food choices data from this and similar studies to develop models that predict food retail demand during pandemics and other crises (see Drivers of Consumer Food Choices; Figures 3, 4; Table 4).

- Programs that enhance consumer access to fresh food outside the scope of food retail, including home gardening or community gardens (Figure 5; Table 5).

- Prevention of excessive consumption of convenience and other energy-dense food in times of crisis, considering emerging working environments such as home office and their implications for the potential of households to prepare healthy food. This may involve the maintenance of childcare programs, even during lockdowns (see sections Impact of the COVID-19 Pandemic on US Food Supply Chains and Retail, Impact of COVID-19 Pandemic on Grocery Store Consumer Food Choices; Figures 1, 2; Table 4).

- Insurance of food and nutrition security for all households through expanded benefits and flexibilities in nutrition assistance in times when emergency food is needed (see sections Semi-Structured Interviews, Impact of COVID-19 Pandemic on Grocery Store Consumer Food Choices).

- Instruments to assure that SNAP and other programs addressing food insecure people are used for reasonable food purchases (see sections Pandemic Intervention Authority in the US, Study Goal, Environment, and Limitations).

- Prevention of extreme stress for food retail workers and their exploitation during pandemics through training programs and labor legislation (see sections Semi-Structured Interviews, Impact of COVID-19 Pandemic on Grocery Store Workforce and Economy).

- Centralized information about food availability and shortages available for consumers (see section Study Goal, Environment, and Limitations).

- Strong legal protection of food retail workers and managers against misbehaving customers (see sections Semi-Structured Interviews, Impact of COVID-19 Pandemic on Grocery Store Workforce and Economy).

- Organized redistribution of skilled food system workers from places that may face closures and decreasing workforce demand (restaurants) to places where these workers are needed during a food system shock, specifically food production, processing, distribution, and retail (see sections Semi-Structured Interviews, Impact of COVID-19 Pandemic on Grocery Store Workforce and Economy).

- Fiscal and economic programs that ensure the persistence of local food retailers during a pandemic as well as reasonable pricing for consumers (see section Impact of COVID-19 Pandemic on Grocery Store Workforce and Economy).

Despite the importance of decreasing the spread of diseases such as COVID-19, legal interventions during pandemics must consider implications on consumers' access to nutritious, affordable, and convenient food, as well as on local food retailers and their employees.

\section{DATA AVAILABILITY STATEMENT}

The original contributions presented in the study are included in the article/Supplementary Material, further inquiries can be directed to the corresponding author.

\section{ETHICS STATEMENT}

The studies involving human participants were reviewed and approved by Institutional Review Board (IRB) at Montana State University (IRB approval number: RE012121-EX). The patients/participants provided their written informed consent to participate in this study. Written informed consent was obtained from the individual(s) for the publication of any potentially identifiable images or data included in this article.

\section{AUTHOR CONTRIBUTIONS}

$\mathrm{RE}$ and $\mathrm{CB}-\mathrm{S}$ led the study conception and design and conducted the data interpretation. RE led the acquisition of data, conducted the data analysis, and led the drafting of the manuscript with essential contributions from CB-S. 


\section{FUNDING}

This work was supported by the Montana State University Initiative for Regulation and Applied Economic Analysis (IRAEA) funded by the Charles Koch Foundation.

\section{ACKNOWLEDGMENTS}

We are grateful to the grocery store in Bozeman, Montana, whose manager granted us access to its store sales data. We also would like to thank the four grocery store professionals who

\section{REFERENCES}

Aboelenien, A., Arsel, Z., and Cho, C. H. (2021). Passing the buck versus sharing responsibility: the roles of government, firms, and consumers in marketplace risks during COVID-19. J. Assoc. Cons. Res. 6, 149-158. doi: 10.1086/711733

Aday, S., and Aday, M. S. (2020). Impact of COVID-19 on the food supply chain. Food Qual. Safety 4, 167-180. doi: 10.1093/fqsafe/fyaa024

Afshin, A., Sur, P. J., Fay, K. A., Cornaby, L., Ferrara, G., Salama, J. S., et al. (2019). Health effects of dietary risks in 195 countries, Health effects of dietary risks in 195 countries, 1990-2017: a systematic analysis for the Global Burden of Disease Study 2017: a systematic analysis for the Global Burden of Disease Study 2017. Lancet 393, 1958-1972. doi: 10.1016/S0140-6736(19)30041-8

Ahmad, F. B., and Anderson, R. N. (2021). The leading causes of death in the US for 2020. JAMA 325, 1829-1830. doi: 10.1001/jama.2021.5469

American Psychological Association (2021). Slightly More Than 6 in 10 U.S. Adults (61\%) Report Undesired Weight Change Since Start of Pandemic. Washington, DC: APA.

Belarmino, E. H., Bertmann, F., Wentworth, T., Biehl, E., Neff, R., and Niles, M. T. (2020). Early COVID-19 Impacts on Food Retail and Restaurants: Consumer Perspectives From Vermont. Burlington, VT: University of Vermont. Available online at: https://scholarworks.uvm.edu/calsfac/24/ (accessed April 6, 2021).

Béné, C. (2020). Resilience of local food systems and links to food security-a review of some important concepts in the context of COVID-19 and other shocks. Food Security 12, 805-822. doi: 10.1007/s12571-020-01076-1

Bhattacharya, D. (2012). "Trade and health: Emergent paradigms and case studies in infectious diseases, “ in Global Health Disputes and Disparities (London: Routledge), 107-125. doi: 10.4324/9780203080917-11

Blum, S. C. (2020). Federalism: Fault or feature-an analysis of whether the united states should implement a federal pandemic statute. Washburn Law J. 60, 1-62.

Boyacı-Gündüz, C. P., Ibrahim, S. A., Wei, O. C., and Galanakis, C. M. (2021). Transformation of the food sector: security and resilience during the COVID19 pandemic. Foods 10:497. doi: 10.3390/foods10030497

Brinkerhoff, K. M., Brewster, P. J., Clark, E. B., Jordan, K. C., Cummins, M. R., and Hurdle, J. F. (2011). Linking supermarket sales data to nutritional information: an informatics feasibility study. MIA Annu. Symp. Proc. 2011, 598-606.

Buchbinder, E. (2010). Beyond checking: experiences of the validation interview. Qual. Social Work 10, 106-122. doi: 10.1177/14733250103 70189

Byker-Shanks, C., Calloway, E. E., Parks, C. A., and Yaroch, A. L. (2020a). Scaling up measurement to confront food insecurity in the USA. Transl. Behav. Med. 10, 1382-1389. doi: 10.1093/tbm/ibaa112

Byker-Shanks, C., Grocke, M., Shanks, J. D., Weber, E., and Scanlon, K. (2021). The Impact of COVID-19 on the Health of Montanans. Bozeman, MT: Montana State University. Available online at: https://www.montana.edu/ cairhe/projects/byker-shanks/COVID-19-food-security.html (accessed April 12, 2021).

Byker-Shanks, C., Hingle, M. D., Parks, C. A., and Yaroch, A. L. (2020b). The COVID-19 pandemic: a watershed moment to strengthen food security across the US food system. Am. J. Public Health 110, 1133-1134. doi: 10.2105/AJPH.2020.305760 participated in the semi-structured interviews. We thank Beryl Martina Wytcherley for supporting the interview analysis, Selena Ahmed for her significant contribution to our grant proposal, and Christopher Graff for facilitating our networking with the Bozeman community.

\section{SUPPLEMENTARY MATERIAL}

The Supplementary Material for this article can be found online at: https://www.frontiersin.org/articles/10.3389/fsufs. 2021.708504/full\#supplementary-material
CDC (2019). Specific Laws and Regulations Governing the Control of Communicable Diseases. Washington, DC: CDC. Available online at: https://www.cdc.gov/ quarantine/specificlawsregulations.html (accessed April 8, 2020).

CDC (2020a). Legal Authorities for Isolation and Quarantine. Washington, DC: CDC. Available online at: https://www.cdc.gov/quarantine/ aboutlawsregulationsquarantineisolation.html (accessed April 8, 2020).

CDC (2020b). People Who Are at Higher Risk for Severe Illness. Washington, DC. Available online at: https://www.cdc.gov/coronavirus/2019-ncov/need-extraprecautions/people-at-higher-risk.html (accessed May 1, 2020).

CDC (2020c). What You Can Do. Washington, DC: CDC. Available online at: https://www.cdc.gov/coronavirus/2019-ncov/need-extra-precautions/whatyou-can-do.html (accessed May 1, 2020).

Chaganti, S., Graves, E., Higgins, A., Mattingly, M., Savage, S., and Tonsberg, C. (2020). The Effects of the Novel Coronavirus Pandemic on Service Workers in New England. Federal Reserve Bank of Boston Issue Brief 2020-21, 1-20. Available Online at: https://www.bostonfed.org/publications/communitydevelopment-issue-briefs/2020/the-effects- of-the-novel-coronaviruspandemic-on-service-workers-in-new-england.aspx (accessed March 31, 2020).

Chenarides, L., Grebitus, C., Lusk, J. L., and Printezis, I. (2021). Food consumption behavior during the COVID-19 pandemic. Agribusiness 37, 44-81. doi: 10.1002/agr.21679

Cole, J. P. (2014). Federal and State Quarantine and Isolation Authority Washington, DC: Congressional Research Service.

Conley, K. L., and Lusk, J. L. (2019). What to eat when having a millennial over for dinner. Appl. Econ. Persp. Policy 41, 56-70. doi: 10.1093/aepp/ppy008

Corkery, M., and Yaffee-Bellan, D. (2020, April 18). The food chain's weakest link: slaughterhouses. New York Times.

Cranfield, J. A. L. (2020). Framing consumer food demand responses in a viral pandemic. Canad. J. Agric. Econ. 68, 151-156. doi: 10.1111/cjag.12246

Data USA (2021). Gallatin County, MT. Deloitte: Massachusetts Institute of Technology Collective Learning Group, and Datawheel. Available onlien at: https://datausa.io/profile/geo/gallatin-county-mt (accessed April 13, 2021).

De Sá, J. P. M. (2007). Applied Statistics Using SPSS, Statistica, MatLab and R. Berlin: Springer Science \& Business Media. doi: 10.1007/978-3-540-71972-4

DeBroff, S. (2020). How COVID-19 Has Impacted Consumer Food Habits. Food Manufacturing. Available online at: https://www.foodmanufacturing.com/ consumer-trends/blog/21133823/how-covid19-has-impacted-consumerfood-habits (accessed April 2, 2021).

Ding, H. (2009). Rhetorics of alternative media in an emerging epidemic: SARS, censorship, and extra-institutional risk communication. Tech. Commun. Quart. 18, 327-350. doi: 10.1080/10572250903149548

Dyal, J., Grant, M., and Broadwater, K. (2020). COVID-19 Among Workers in Meat and Poultry Processing Facilities - 19 States, April 2020. Washington, DC: CDC. Available onlien at: https:/www.cdc.gov/mmwr/volumes/69/wr/ mm6918e3.htm (accessed November 6, 2020).

Ellison, B., McFadden, B., Rickard, B. J., and Wilson, N. L. W. (2021). Examining food purchase behavior and food values during the COVID-19 pandemic. Appl. Econ. Persp. Policy 43, 58-72. doi: 10.1002/aepp.13118

Feldman, B. (2020). Farmers Markets Across Nation Face Potential Economic Crisis From COVID-19. Albany, CA: Farmers Market Coalition. Available online at: 
https://farmersmarketcoalition.org/farmers-markets-across-the-nation-facea-precarious-economic-situation-due-to-covid-19/ (accessed April 5, 2021).

Fitzsimons, G. J., and Lehmann, D. R. (2004). Reactance to recommendations: when unsolicited advice yields contrary responses. Market. Sci. 23, 82-94. doi: $10.1287 / \mathrm{mksc} .1030 .0033$

Frost, R. O., and Hartl, T. L. (1996). A cognitive-behavioral model of compulsive hoarding. Behav. Res. Ther. 34, 341-350. doi: 10.1016/0005-7967(95)00071-2

Fuller, D., Engler-Stringer, R., and Muhajarine, N. (2015). Examining food purchasing patterns from sales data at a full-service grocery store intervention in a former food desert. Prev. Med. Rep. 2, 164-169. doi: 10.1016/j.pmedr.2015.02.012

Galea, S., Merchant, R. M., and Lurie, N. (2020). The mental health consequences of COVID-19 and physical distancing: the need for prevention and early intervention. JAMA Intern. Med. 180, 817-818. doi: 10.1001/jamainternmed.2020.1562

Gallatin County (2020). Emergency Health Rule Relating to COVID-19. (Bozeman, MT: G.C.-C.H. Department).

Giesler, M., and Thompson, C. J. (2016). A tutorial in consumer research: process theorization in cultural consumer research. J. Cons. Res. 43, 497-508. doi: $10.1093 /$ jcr/ucw047

Goddard, E. (2020). The impact of COVID-19 on food retail and food service in Canada: preliminary assessment. Canad. J. Agric. Econ. 10. doi: $10.1111 /$ cjag. 12243

Goodwin, R., Haque, S., Neto, F., and Myers, L. B. (2009). Initial psychological responses to Influenza A, H1N1 ("Swine flu“). BMC Infect. Dis. 9, 1-6. doi: 10.1186/1471-2334-9-166

Goolsbee, A., and Syverson, C. (2021). Fear, lockdown, and diversion: comparing drivers of pandemic economic decline 2020. J. Public Econ. 193:104311. doi: 10.1016/j.jpubeco.2020.104311

Gostin, L. O., Hodge, J. G., and Wiley, L. F. (2020). Presidential powers and response to COVID-19. JAMA 323, 1547-1548. doi: 10.1001/jama.2020.4335

Gostin, L. O., and Wiley, L. F. (2020). Governmental public health powers during the COVID-19 pandemic: stay-at-home orders, business closures, and travel restrictions. JAMA 323, 2137-2138. doi: 10.1001/jama.2020.5460

Gray, R. S. (2020). Agriculture, transportation, and the COVID-19 crisis. Canad. J. Agric. Econ. 68, 239-243. doi: 10.1111/cjag. 12235

Hafiz, H., Oei, S. -Y., Ring, D. M., and Shnitser, N. (2020). Regulating in Pandemic: Evaluating Economic and Financial Policy Responses to the Coronavirus Crisis. Boston College Law School Legal Studies Research Paper 527, 1-90. Available Online at: https://papers.ssrn.com/sol3/papers.cfm?abstract_id=3555980

Hall, M. A., Mello, M. M., and Studdert, D. M. (2020). The legal authority for states' stay-at-home orders. N. Engl. J. Med. 383:e29. doi: 10.1056/NEJMp2019662

Harrison, M. (2016). "Pandemics," in The Routledge History of Disease, ed. M. Jackson. (Milton Park: Routledge), 128-146. doi: 10.4324/978131554 3420-8

Healthy Gallatin (2020). Reopening Gallatin County. Bozeman, MT: Gallatin CityCounty Health Department. Available online at: https://www.healthygallatin. org/coronavirus-covid-19/reopening/ (accessed April 16, 20201).

Hedberg, E. C., and Ayers, S. (2015). The power of a paired t-test with a covariate. Social Sci. Res. 50, 277-291. doi: 10.1016/j.ssresearch.2014.12.004

Hirvonen, K., Bai, Y., Headey, D., and Masters, W. A. (2020). Affordability of the EAT Lancet reference diet: a global analysis. Lancet Global Health 8, e59-e66. doi: 10.1016/S2214-109X(19)30447-4

Hobbs, J. E. (2020). Food supply chains during the COVID-19 pandemic. Canad. J. Agric. Econ. 68, 171-176. doi: 10.1111/cjag.12237

Huizar, M. I., Arena, R., and Laddu, D. R. (2020). The global food syndemic: the impact of food insecurity, malnutrition and obesity on the healthspan amid the COVID-19 pandemic. Progr. Cardiovasc. Dis. 64, 105-107. doi: 10.1016/j.pcad.2020. 07.002

Information Resources Inc. (2020). Changes in Dollar Sales of Edible Groceries Due to the Coronavirus Pandemic in the United States in March 2020, by Category. Available online at: www.statista.com/statistics/1105478/coronavirus-changesin-edible-grocery-purchases-united-states/ (accessed February 15, 2021).

Johansson, R. (2020). Another Look at Availability and Prices of Food Amid the COVID-19 Pandemic. Wasgington, DC: USDA. Available online at: https:// www.usda.gov/media/blog/2020/05/28/another-look-availability-and-pricesfood-amid-covid-19-pandemic (accessed September 6, 2020).
Kalil, A. C. (2020). Treating COVID-19-off-label drug use, compassionate use, and randomized clinical trials during pandemics. JAMA 323, 1897-1898. doi: 10.1001/jama.2020.4742

Kamphuis, C. B., de Bekker-Grob, E. W., and van Lenthe, F. J. (2015). Factors affecting food choices of older adults from high and low socioeconomic groups: a discrete choice experiment. Am. J. Clin. Nutr. 101, 768-774. doi: $10.3945 /$ ajcn.114.096776

Kirk, C. P., and Rifkin, L. S. (2020). I'll trade you diamonds for toilet paper: consumer reacting, coping and adapting behaviors in the COVID-19 pandemic. J. Bus. Res. 117, 124-131. doi: 10.1016/j.jbusres.2020.05.028

Krebs-Smith, S. M., Pannucci, T. E., Subar, A. F., Kirkpatrick, S. I., Lerman, J. L., Tooze, J. A., et al. (2018). Update of the healthy eating index: HEI-2015. J. Acad. Nutr. Diet. 118, 1591-1602. doi: 10.1016/j.jand.2018.05.021

Kuckartz, U. (2014). "Three basic methods of qualitative text analysis," in Qualitative Text Analysis: A Guide to Methods, Practice and Using Software, ed U. Kuckartz. (London: SAGE), 65-121. doi: 10.4135/9781446288719

Laato, S., Islam, A. K. M. N., Farooq, A., and Dhir, A. (2020). Unusual purchasing behavior during the early stages of the COVID-19 pandemic: The stimulus-organism-response approach. J. Retail. Cons. Serv. 57:102224. doi: 10.1016/j.jretconser.2020.102224

Laborde, D., Martin, W., Swinnen, J., and Vos, R. (2020). COVID-19 risks to global food security. Science 369, 500-502. doi: 10.1126/science.abc4765

Leech, N. L., and Onwuegbuzie, A. J. (2011). Beyond constant comparison qualitative data analysis: Using NVivo. School Psychol. Quart. 26:70. doi: $10.1037 / \mathrm{a} 0022711$

Leone, L. A., Fleischhacker, S., Anderson-Steeves, B., Harper, K., Winkler, M., Racine, E., et al. (2020). Healthy food retail during the COVID-19 pandemic: challenges and future directions. Int. J. Environ. Res. Public Health 17:7397. doi: 10.3390/ijerph17207397

Lowrey, N. (2020), April 17. Need for food assistance skyrocketing for South Dakota residents during pandemic. Argus Leader.

Luckstead, J., Nayga Jr, R. M., and Snell, H. A. (2021). Labor issues in the food supply chain amid the COVID-19 pandemic. Appl. Econ. Persp. Policy 43, 382-400. doi: 10.1002/aepp.13090

Lusk, J. L., and Briggeman, B. C. (2009). Food values. Am. J. Agric. Econ. 91, 184-196. doi: 10.1111/j.1467-8276.2008.01175.x

Martin-Neuninger, R., and Ruby, M. B. (2020). What does food retail research tell us about the implications of coronavirus (COVID-19) for grocery purchasing habits? Front. Psychol. 11, 1448-1448. doi: 10.3389/fpsyg.2020.01448

McLoughlin, G. M., Fleischhacker, S., Hecht, A. A., McGuirt, J., Vega, C., Read, M., et al. (2020). Feeding students during COVID-19-related school closures: a nationwide assessment of initial responses. J. Nutr. Educ. Behav. 52, 1120-1130. doi: 10.1016/j.jneb.2020.09.018

Melo, G. (2020). The path forward: US consumer and food retail responses to COVID-19. Choices 35:3.

Mendez-Carbajo, D. (2021). Consumer Spending and the COVID-19 Pandemic. Federal Reserve Bank. Washington, DC: Consumer Spending and the COVID19 Pandemic.

Metzger, L. E. (2010). Nutrition Labeling. (Boston, MA: Springer US).

Montana Budget and Policy Center (2020). Food Prices and Hunger are on the Rise in Montana. Helena, MT: Montana Budget and Policy Center. Available online at: https://montanabudget.org/post/food-prices-and-hunger-are- on-the-risein-montana (accessed November 30, 2020).

Montana Food Bank Network (2020). Montana Food Bank Network's Response to COVID-19. Missoula, MT: Montana Food Bank Network. Available online at: https://mfbn.org/2020/08/montana-food-bank-networks-responseto-covid-19/ (accessed December 1, 2020).

Monteiro, C. A., Moubarac, J. C., Cannon, G., Ng, S. W., and Popkin, B. (2013). Ultra-processed products are becoming dominant in the global food system. Obesity Rev. 14, 21-28. doi: 10.1111/obr.12107

Morales, D. X., Morales, S. A., and Beltran, T. F. (2020). Racial/ethnic disparities in household food insecurity during the COVID-19 pandemic: a nationally representative study. J. Racial Ethnic Health Dispar. 14, 1-15. doi: 10.1007/s40615-020-00892-7

MTN News (2020). Some Grocery Stores Begin Offering Periodic "Seniors Only" Shopping. KRTV 3, Great Falls. Available online at: https://www.krtv.com/ news/montana- and-regional-news/some-grocery-stores-begin-offeringperiodic-seniors-only-shopping (accessed April 16, 2021). 
Naja, F., and Hamadeh, R. (2020). Nutrition amid the COVID-19 pandemic: a multi-level framework for action. Euro. J. Clin. Nutr. 74, 1117-1121. doi: 10.1038/s41430-020-0634-3

Native Hope (2020). COVID-19 Increases Food Insecurity on Reservations. Chamberlain, SD: Native Hope. Available online at: https://blog.nativehope. org/covid-19-increases-food-insecurity-on-reservation (accessed December 1, 2020).

Nicola, M., Alsafi, Z., Sohrabi, C., Kerwan, A., Al-Jabir, A., Iosifidis, C., et al. (2020). The socio-economic implications of the coronavirus and COVID-19 pandemic: a review. Int. J. Surg. 78, 185-193. doi: 10.1016/j.ijsu.2020.04.018

Nicosia, J. (2005). Avian flu: the consumer costs of preparing for global pandemic. Loyola Cons. Lab Rev. 18, 479-502.

Niles, M. T., Bertmann, F., Belarmino, E. H., Wentworth, T., Biehl, E., and Neff, R. (2020). The early food insecurity impacts of COVID-19. Nutrients 12:2096. doi: $10.3390 /$ nu12072096

Orden, D. (2020). Resilience test of the North American Food System. Canad. J. Agric. Econ. 68, 215-217. doi: 10.1111/cjag.12238

Pantano, E., Pizzi, G., Scarpi, D., and Dennis, C. (2020). Competing during a pandemic? Retailers' ups and downs during the COVID-19 outbreak. J. Bus. Res. 116, 209-213. doi: 10.1016/j.jbusres.2020.05.036

Parmet, W. E., and Sinha, M. S. (2020). Covid-19-the law and limits of quarantine. N. Engl. J. Med. 382:e28. doi: 10.1056/NEJMp2004211

Patrick, S. W., Henkhaus, L. E., Zickafoose, J. S., Lovell, K., Halvorson, A., Loch, S., et al. (2020). Well-being of parents and children during the COVID-19 pandemic: a national survey. Pediatrics 146:e2020016824. doi: 10.1542/peds.2020-016824

Poppick, L. (2020). The Effects of COVID-19 Will Ripple through Food Systems. New York City, NY: Springer Nature. Available online at: https://www. scientificamerican.com/article/the-effects- of-covid-19-will-ripple-throughfood-systems/ (accessed March 26, 2020].

Power, M., Doherty, B., Pybus, K., and Pickett, K. (2020). How Covid-19 has exposed inequalities in the UK food system: The case of UK food and poverty. Emerald Open Res. 2:13539. doi: 10.35241/emeraldopenres.13539.1

Reeves, M., Carlsson-Szlezak, P., Whitaker, K., and Abraham, M. (2020). Sensing and Shaping the Post-COVID Era. Boston, MA: The BCG Henderson Institute.

Ren, X. (2020). Pandemic and lockdown: a territorial approach to COVID19 in China, Italy and the United States. Euras. Geogr. Econ. 61, 423-434. doi: 10.1080/15387216.2020.1762103

Roe, B. E., Bender, K., and Qi, D. (2021). The impact of COVID-19 on consumer food waste. Appl. Econ. Persp. Policy 43, 401-411. doi: 10.1002/aepp.13079

Ross, A., and Willson, V. L. (2017). "Paired samples T-test," in Basic and Advanced Statistical Tests (Leiden: Brill Publishers), 17-19. doi: 10.1007/978-94-6351-086-8

Saldaña, J. (2015). The Coding Manual for Qualitative Researchers. Newbury Park, CA: Sage.

Samartin, S., and Chandra, R. K. (2001). Obesity, overnutrition and the immune system. Nutr. Res. 21, 243-262. doi: 10.1016/S0271-5317(00)00255-4

Schanzenbach, D., and Pitts, A. (2020). Estimates of food insecurity during the COVID-19 crisis: results from the COVID Impact Survey, week 1 (April 20-26, 2020). Instit. Policy Res. Rapid Res. Rep. 13, 1-14.

Scully, M., Dixon, H., and Wakefield, M. (2009). Association between commercial television exposure and fast-food consumption among adults. Public Health Nutr. 12, 105-110. doi: 10.1017/S1368980008002012

Sharif, A., Aloui, C., and Yarovaya, L. (2020). COVID-19 pandemic, oil prices, stock market, geopolitical risk and policy uncertainty nexus in the US economy: fresh evidence from the wavelet-based approach. Int. Rev. Finan. Anal. 70:101496. doi: 10.1016/j.irfa.2020.101496

Sherman, D. (2020). Bullock Shuts Down Dine-In Restaurants and Other Businesses Statewide. Billings, MT: KTVQ News.

Singh, S., Kumar, R., Panchal, R., and Tiwari, M. K. (2020). Impact of COVID-19 on logistics systems and disruptions in food supply chain. Int. J. Prod. Res. 59, 1993-2008. doi: 10.1080/00207543.2020.1792000

State of Montana (2020a). "Directive Implementing Executive Orders 2-2020 and 3-2020 and extending certain Directives through April 24, 2020", (ed.) O.o.t. Governor. (Helena, MT: State of Montana).

State of Montana (2020b). Directive implementing Executive Orders 2-2020 and 3-2020 and Providing Guidance for the Phased Reopening of Montana and Establishing Conditions for Phase One. Helena, MT: State of Montana.
State of Montana (2020c). Directive Implementing Executive Orders 2-2020 and 32020 and Providing Mandatory Quarantine for Certain Travelers Arriving in Montana From Another State or Country. Helena, MT: State of Montana.

State of Montana (2020d). Executive Order Amending Executive Order 2-2020 and Providing that the State of Emergency Runs Concurrent With the President's Emergency Declaration. Helena, MT: State of Montana.

State of Montana (2020e). Executive Order Declaring a State of Emergency to Exist Within the State of Montana Related to the Communicable Disease COVID-19 Novel Coronavirus. Helena, MT: State of Montana.

Statista (2021). Food - United States. New York City, NY: Statista Inc. Available online at: www.statista.com/outlook/cmo/food/united-states (accessed April 14, 2021).

Stephens, E. C., Martin, G., van Wijk, M., Timsina, J., and Snow, V. (2020). Impacts of COVID-19 on agricultural and food systems worldwide and on progress to the sustainable development goals. Agric. Syst. 183:102873. doi: 10.1016/j.agsy.2020.102873

Sterman, J. D., and Dogan, G. (2015). "I'm not hoarding, I'm just stocking up before the hoarders get here." Behavioral causes of phantom ordering in supply chains. J. Oper. Manag. 39, 6-22. doi: 10.1016/j.jom.2015. 07.002

Taylor, D. B. (2020), April 7. A timeline of the coronavirus pandemic. The New York Times.

Timmer, C. P. (2012). Behavioral dimensions of food security. Proc. Natl. Acad. Sci. U.S.A. 109, 12315-12320. doi: 10.1073/pnas.09132 13107

Timmons, D., and Wang, Q. (2010). Direct food sales in the United States: evidence from state and county-level data. J. Sustain. Agric. 34, 229-240. doi: $10.1080 / 10440040903482605$

Torales, J., O'Higgins, M., Castaldelli-Maia, J. M., and Ventriglio, A. (2020). The outbreak of COVID-19 coronavirus and its impact on global mental health. Int. J. Soc. Psychiatry. 66, 317-320. doi: 10.1177/00207640209 15212

Torero, M. (2020). Without food, there can be no exit from the pandemic. Nature 580:588. doi: 10.1038/d41586-020-01181-3

U.S. Supreme Court (2000). United States v. Morrison, case No. 529 US 598. U.S. Court. (Washington, DC: US Supreme Court Center), 461-470. Available Online at: https://supreme.justia.com/cases/federal/us/529/598/case.pdf

Upton, G. J. (1992). Fisher's exact test. J. R. Stat. Soc. 155, 395-402. doi: $10.2307 / 2982890$

US Bureau of Labor Statistics (2021). BLS Data Finder 1.1. Washington, DC: United States Department of Labor. Available online at: https://beta.bls.gov/ dataQuery/find?st $=0 \& \mathrm{r}=20 \& \mathrm{~s}=$ popularity\%3AD\&more $=0 . S . \& q=$ food $\$+\$$ U.S. note (accessed March 29, 2021).

US Census Bureau (2020a). Food Services and Drinking Places: U.S. Total - Seasonally Adjusted Sales - Monthly. Washington, DC: US Census Bureau. Available online at: https://www.census.gov/econ/currentdata/ dbsearch?program=MRTS\&startYear=1992\&endYear=2019\&categories= 722\&dataType $=$ SM\&geoLevel=US\&adjusted $=1 \&$ notAdjusted $=1 \&$ submit $=$ GET\$+\$DATA\&releaseScheduleId $=($ accessed April 14, 2021).

US Census Bureau (2020b). Monthly Retail Trade Report. Washington, DC: US Census Bureau. Available online at: https://www.census.gov/retail/marts/www/ timeseries.html (accessed March 31, 2021).

US Census Bureau (2021a). Grocery Stores. Washington, DC: US Census Bureau. Available online at: https://www.census.gov/retail/marts/www/adv44510.txt (accessed April 14, 2021).

US Census Bureau (2021b). Quick Facts Gallatin County, Montana. Washington, DC: US Census Bureau. Available online at: https://www.census.gov/ quickfacts/fact/table/gallatincountymontana/EDU685219\#EDU685219 (accessed April 13, 2021).

US Department of Agriculture (2020). Food Security Status of U.S. Households in 2019. Washington, DC: USDA. Available online at: https://www.ers.usda. gov/topics/food-nutrition-assistance/food-security-in-the-us/key-statisticsgraphics.aspx (accessed May 5, 2021).

US Department of Agriculture (2021). Food Data Central. Available online at: https://fdc.nal.usda.gov/ (accessed May 11, 2021).

US Department of Health and Human Services and US Department of Agriculture (2015). 2015-2020 Dietary Guidelines for Americans, 8th edn. Washington, DC: USDA. 
US Food and Drug Administration (2020). Best Practices for Retail Food Stores, Restaurants, and Food Pick-Up/Delivery Services During the COVID-19 Pandemic. Washington, DC: FDA. Available online at: https://www.fda. gov/food/food-safety-during-emergencies/best-practices-retail-food-storesrestaurants-and-food-pick-updelivery-services-during-covid-19 (accessed April 5, 2021).

Walters, L., Wade, T., and Suttles, S. (2020). Food and agricultural transportation challenges amid the COVID-19 pandemic. Choices 35:3.

Wang, Y., Xu, R., Schwartz, M., Ghosh, D., and Chen, X. (2020). COVID-19 and retail grocery management: insights from a broad-based consumer survey. IEEE Eng. Manag. Rev. 48, 202-211. doi: 10.1109/EMR.2020.3011054

Wen, Z., Huimin, G., and Kavanaugh, R. R. (2005). The impacts of SARS on the consumer behaviour of chinese domestic tourists. Curr. Issues Tour. 8, 22-38. doi: $10.1080 / 13683500508668203$

Werner, E., Stein, J., and DeBonis, M. (2020) March 17. White House expresses support for immediate cash payments to Americans as part of coronavirus stimulus package. Washington Post.

Wolfson, J. A., Ishikawa, Y., Hosokawa, C., Janisch, K., Massa, J., and Eisenberg, D. M. (2021). Gender differences in global estimates of cooking frequency prior to COVID-19. Appetite 161:105117. doi: 10.1016/j.appet.2021.105117

Wolfson, J. A., and Leung, C. W. (2020). Food insecurity and COVID19: disparities in early effects for US adults. Nutrients 12:1648. doi: $10.3390 /$ nu12061648
Xiong, J., Lipsitz, O., Nasri, F., Lui, L. M., Gill, H., Phan, L., et al. (2020). Impact of COVID-19 pandemic on mental health in the general population: a systematic review. J. Affect. Disord. 277, 55-64. doi: 10.1016/j.jad.2020.08.001

Zurayk, R. (2020). Pandemic and food security. J. Agric. Food Syst. Commun. Dev. 9, 1-5. doi: 10.5304/jafscd.2020.093.014

Conflict of Interest: The authors declare that the research was conducted in the absence of any commercial or financial relationships that could be construed as a potential conflict of interest.

Publisher's Note: All claims expressed in this article are solely those of the authors and do not necessarily represent those of their affiliated organizations, or those of the publisher, the editors and the reviewers. Any product that may be evaluated in this article, or claim that may be made by its manufacturer, is not guaranteed or endorsed by the publisher.

Copyright (๑) 2022 Ebel and Byker-Shanks. This is an open-access article distributed under the terms of the Creative Commons Attribution License (CC BY). The use, distribution or reproduction in other forums is permitted, provided the original author(s) and the copyright owner(s) are credited and that the original publication in this journal is cited, in accordance with accepted academic practice. No use, distribution or reproduction is permitted which does not comply with these terms. 